Measuring Realistic and Symbolic Threats of COVID-19 and their Unique Impacts on Wellbeing and Adherence to Public Health Behaviors

Frank J. Kachanoff, Yochanan E. Bigman, Kyra Kapsaskis, \& Kurt Gray

The University of North Carolina at Chapel Hill

May 12, 2020

(Updated December 1, 2020) *

Wordcount of abstract, key words, text, footnotes: 5,000

Authors' Note: This is a preprint of this manuscript, currently in press at Social Psychological and Personality Science (SPPS). This paper is not the copy of record and may not exactly replicate the authoritative document that will be published in SPPS.

We recommend reading the official copy when it is uploaded on SPPS which we have made free to access.

*We updated this paper on July $22^{\text {nd }} 2020$ to correct two small mistakes we noticed in the Tables during the proofing process, as well as some other small corrections. In Table 1, the mean ages were not correctly reported. In Table 4, the reliability for TIPI - Conscientiousness was incorrectly reported.

*We updated this paper on December $1^{\text {st }}, 2020$ to correct small errors we detected in the results of the CFA and SEM analysis for Study 2 (please see Figure 2 and Table 8, and the CFA description on p.19). These errors were due to some of the rows in our data become corrupted when we transferred our data file from an SPSS to CSV file. None of these changes alter the significance of our key findings or the conclusions we can draw from this research. We have also updated and corrected Supplemental Table 3 and the corresponding footnote 4 in text (p. 28).

Correspondence can be made to Frank J. Kachanoff at fkach@email.unc.edu.

Data, analysis script, and supplemental materials is available on OSF: https://osf.io/p39ru/?view only=55abd11ea00744abae5924a02de795c4.

This research was funded by the Charles Koch Foundation 


\begin{abstract}
COVID-19 threatens lives, livelihoods, and civic institutions. Although restrictive public health behaviors such as social distancing help manage its impact, these behaviors can further sever our connections to people and institutions that affirm our identities. Three studies $(\mathrm{N}=1,195)$ validated a brief 10-item COVID-19 threat scale that assesses 1) realistic threats to physical or financial safety, and 2) symbolic threats to one's sociocultural identity. Studies reveal that both realistic and symbolic threat predict higher distress and lower wellbeing, and demonstrate convergent validity with other measures of threat sensitivity. Importantly, the two kinds of threat diverge in their relationship to restrictive public health behaviors: Realistic threat predicted greater self-reported adherence, whereas symbolic threat predicted less self-reported adherence to social-disconnection behaviors. Symbolic threat also predicted using creative ways to affirm identity even in isolation. Our findings highlight how social psychological theory can be leveraged to understand and predict people's behavior in pandemics.
\end{abstract}

$($ wordcount $=149)$

Key words: COVID-19, Scale Validation, Realistic Threat, Symbolic Threat, Psychological Health, Public Health. 
Realistic and Symbolic Threats of COVID-19

\section{Measuring Realistic and Symbolic Threats of COVID-19 and their Unique Impacts on Well-being and Adherence to Public Health Behaviors}

"An almost 'perfect killing machine'"

(Sanchez, CNN, March 15, 2020, referring to COVID-19)

"America, as we knew it, is on hold"

(Maxouris, Almasy, McLaughlin, CNN, March 12, 2020)

In December 2019, an outbreak of pneumonia was reported in Wuhan, China, which scientists attributed to a novel coronavirus: SARS-CoV-2. In mere months, this novel coronavirus unleashed a global pandemic of COVID-19. The spread of the coronavirus is reshaping social life, and social psychology is at the forefront of studying these changes (e.g., Everett, Colombatto, Chituc, Brady, \& Crockett, 2020; Van Bavel et al., 2020). Essential to this research is understanding — and measuring (Flake, Pek, \& Hehman, 2017)—how people perceive the threat of the virus.

Laypeople (Sanchez, 2020), public health leaders (Hennekens, George, Adirim, \& Johnson, 2020), and social psychologists (Esses, Jackson, \& Armstrong, 1998) often conceptualize threat as realistic threat: a concrete attack on physical or material well-being. Although realistic threat is undoubtedly important, social psychology research highlights another important threat: symbolic threat, an assault on our sociocultural identity (e.g., Kachanoff, Kteily, Khullar, Park, \& Taylor, in press; Stephan, Ybarra, \& Morrison, 2009; Tajfel \& Turner, 1979). Both realistic and symbolic threat likely increase psychological distress, but may differentially predict adherence to the socially restrictive public health behaviors that help contain the pandemic. Here, we validate a ten-item scale that assesses both perceived symbolic 
Realistic and Symbolic Threats of COVID-19

and realistic threat of COVID-19, and examine their consequences for psychological distress, well-being, and adherence to public health behaviors.

\section{Disease and Threat}

Diseases most obviously pose realistic threats to an individual's (or group's) physical health and economic well-being (Hennekens, et al., 2020; Matsuishi, et al., 2012; O’Leary, Jalloh, Neria, 2018; Smith, Keogh-Brown, Barnett, \& Tait, 2009; Viboud, Tam, Fleming, Handel, Miller, \& Simonsen, 2006). Public health officials have warned that COVID-19 is an “almost perfect killing machine” (Sanchez, 2020; also see Hennekens, et al., 2020), and attempts to stop its spread have created mass-unemployment (Davies, Partington \& Wearden, 2020; Patterson, 2020). Not surprisingly then, a recent Pew research poll on Americans' perceptions of threat from COVID-19 focused exclusively on realistic threat (Pew Research Poll, Wave 63.5, March 10, 2020).

Despite the importance of realistic threat, it is not the only threat caused by pandemics. Humans are not just animals with biological needs; we are social animals who depend on our cultural groups for motivation (Oyserman, 2007), psychological well-being (Jetten et al., 2015), and structure (Gelfand et al., 2011). Threats to the “integrity or validity of a group's meaning system [such as] religion, values, belief system, ideology, philosophy, morality, and world view" (Stephan, et al., 2009, p.3-5) are called symbolic threats. COVID-19 poses a symbolic threat because social distancing — the primary method for combatting its spread — may result in a weakened sense of community or national identity. The norms, routines, and institutions of social groups that give people a sense of meaning are unraveled by COVID-19 (ur-Rehman et al., 2020; Maxouris, et al., 2020). COVID-19 means that "America [and all Nations] as we knew it, is on hold" (Maxouris et al., 2020). 
Realistic and Symbolic Threats of COVID-19

Although realistic threats can translate into symbolic threats - if everyone in a group dies, so will its culture - the integrated threat theory of intergroup relations suggests that both kinds of threat can have unique consequences (Stephan \& Stephan, 2000; Zárate, Garcia, Garza, \& Hiltan, 2004). We apply this integrated approach to studying COVID-19, operationalizing realistic threat as its danger to the physical health and financial wellbeing of both individuals and their group, and symbolic threat as its danger to the group's values and identity, as affirmed by core social processes. We do not focus on individual symbolic threats (e.g., personal shame and dishonor; Stephan \& Renfro, 2002) as this seems to be less salient amidst the public discourse surrounding COVID-19. COVID-19 is likely relevant to many group contexts, but we focus on American's national group given its salience in public, political, and global health discussion (e.g., statistics about the number of cases in America). National identity is also salient in people's responses to the virus, as American anti-lock down protestors wave the American flag.

\section{Unique and Sometimes Opposite Consequences of Realistic Versus Symbolic Threats}

Examining realistic and symbolic threat of COVID-19 provides a unique opportunity to extend the predictions of integrated threat theory beyond intergroup contexts and may also help better understand people's response to restrictive yet essential public health behaviors.

One clear prediction is that — as psychological threats — both realistic and symbolic threats should each independently predict increased distress (Horowitz, Wilner, \& Alverez, 1979). Within intergroup contexts, both realistic threat and symbolic threat cause distress (see, Major, Mendes, \& Dovidio, 2013 for review), and so we expected both types of threat to predict feelings of general anxiety during the COVID-19 pandemic (Beck, Epstein, Brown, \& Steer, 1988). We also expected symbolic and realistic threats to both predict two forms of subjective distress often associated with traumatic events (e.g., the 2004 SARS crisis; Hawryluck, Gold, 
Robinson, Pogorski, Galea, \& Styra, 2004): Intrusion of unwanted thoughts about the event (impact intrusion) and deliberate attempts to avoid thinking about the event (impact avoidance; Horowitz, et al., 1979). We speculated that symbolic threat might most robustly predict avoiding thoughts about COVID-19, as impact avoidance can help people maintain the idea that life is unchanged by the pandemic. In contrast, realistic threat might be most robustly associated with impact intrusion, given that realistic concerns about death may be difficult for people to push from their mind. We also predicted that both threats would be associated with diminished psychological well-being (i.e. life-satisfaction; Diener, Emmons, Larsen, Griffin, 1985), reduced positive affect, and greater negative affect, given the associations of these outcomes with other forms of realistic and symbolic group threat (e.g., de la Sablonnière, Auger, Taylor, Crush, \& McDonald, 2012; Usborne \& Taylor, 2010).

Although both kinds of threat should increase distress, they may oppositely predict adherence to restrictive public health behaviors; social distancing helps mitigate realistic threat while simultaneously increasing symbolic threat by undermining group cohesion. Accordingly, we hypothesized that realistic threat would predict increased self-reported support and adherence to socially restrictive public health behaviors like social distancing, whereas feelings of symbolic threat would predict decreased self-reported support and adherence. We also expected realistic threat to be associated with non-restrictive public health behaviors such as hand-washing given that they also mitigate the spread of the virus. However, we did not expect symbolic threat to be associated with non-restrictive public health behaviors given that they do not disrupt the norms and social structures of the group ${ }^{1}$.

\footnotetext{
${ }^{1}$ Our pre-registration did not differentiate between hand-washing and social distancing. We made these distinctions in light of suggestions received during peer-review.
} 
Realistic and Symbolic Threats of COVID-19

Finally, we hypothesized that individuals who experience symbolic threat may be more likely to engage in behaviors that explicitly affirm their symbolic (national) identity such as consuming food, music, or cultural events linked to (national) identity. We also explored whether symbolic threat might increase engagement in virtual substitutes for social behaviors that while not explicitly tied to national identity, were nonetheless socially affirming (e.g., online family get-togethers) $)^{2}$.

\section{Present Research}

We conducted three studies (see Figure 1 for overview) using cross-sectional (Study 1 and 2) and longitudinal (Study 1 and 3) designs in which we assessed the symbolic and realistic threats of COVID-19 within the national context of America.

We had two core objectives. First, we developed a psychometrically sound 10-item scale measuring realistic or symbolic threat in a national group context. To assess factor structure, we used exploratory factor analysis (Study 1), confirmatory factor analysis (Study 2), and invariance analysis (Study 3). To examine convergent validity, we tested whether realistic and symbolic threat were correlated with other measures tied to threat sensitivity. Because coping with the COVID-19 pandemic involves dealing with prolonged uncertainty about health, economic security, or cultural norms, we hypothesized (H1) that individuals who have predispositions to react adversely to uncertainty (i.e., a need for cognitive closure ; Rubin, 2018), who generally perceive threats in the world (i.e., a belief in a dangerous world; Duckitt \& Fisher, 2013), who have unstable emotional responses to stressors (Schneider, 2004), or who value security, conformity, and tradition (Schwartz, Sagiv, Boehnke, 2000) would perceive a higher level of realistic and symbolic threat from COVID-19. To assess divergent validity, we tested the

\footnotetext{
${ }^{2}$ Our decision to split the National identity specific items from the identity-non-specific social behaviors came after pre-registration during the peer-review.
} 
hypothesis (H2) that individual differences less clearly associated with threat sensitivity, such as big-five personality traits (other than emotional instability, Gosling, Rentfrow, \& Swann, 2003), and the other universal values described by Schwartz and colleagues (2000), would not be robustly associated with COVID-19 threat.

Second, as outlined above, we examined the dissociable impact of realistic and symbolic threat on 1) psychological distress and well-being and affect (H3), 2) self-reported adherence to socially restrictive public health behaviors (H4), and 3) new ways of maintaining (national) identity while social distancing (H5). We detail the samples of all three studies in Table 1. See Supplemental Materials for further information regarding the samples and statistical power considerations.

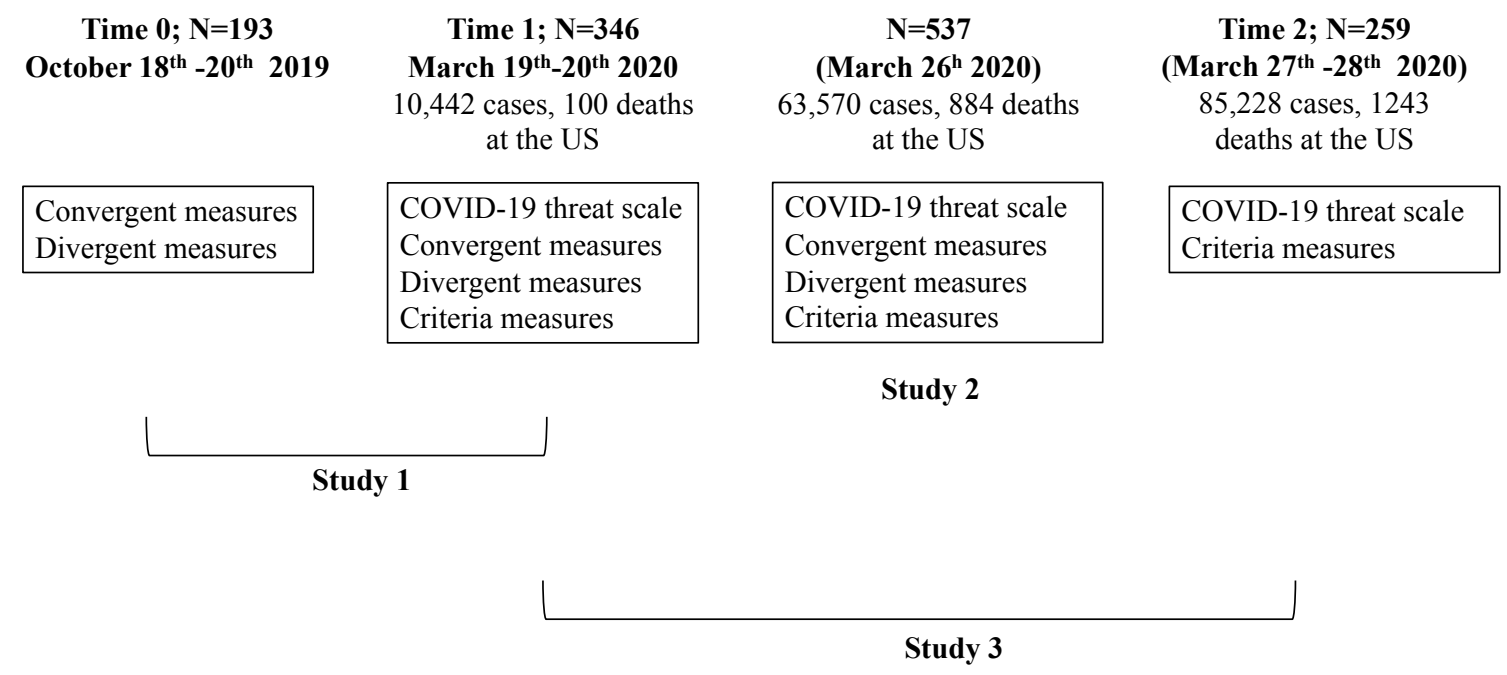

Figure 1. Overview of all studies. 
Realistic and Symbolic Threats of COVID-19

Table 1. Detailed Summary of All Study Samples

\begin{tabular}{|c|c|c|c|}
\hline Study Features & Study 1 & Study 2 & Study 3 \\
\hline $\begin{array}{l}\text { Sample } \\
\text { Characteristics }\end{array}$ & Mturk (American Participants) & Mturk (American Participants) & Mturk (American Participants) \\
\hline $\begin{array}{l}\text { Date of Data } \\
\text { Collection }\end{array}$ & $\begin{array}{l}\text { Time 0: October } 2019 \\
\text { Time 1: March } 19^{\text {th }}-20^{\text {th }} 2020\end{array}$ & March $26^{\text {th }}, 2020$ & $\begin{array}{l}\text { Time 1: March } 19^{\text {th }}-20^{\text {th }} 2020 \text { (participants } \\
\text { from Study 1) } \\
\text { Time 2: March } 27^{\text {th }}-28^{\text {th }} 2020\end{array}$ \\
\hline $\begin{array}{l}\text { Sample Size Prior to } \\
\text { Pre-Registered } \\
\text { Exclusions }\end{array}$ & $\begin{array}{l}\mathrm{N}=399 \text { (a sub-portion of this sample also } \\
\text { completed } \mathrm{T}_{0} \text { ) }\end{array}$ & $\mathrm{N}=550$ & $\mathrm{~N}=311$ \\
\hline $\begin{array}{l}\text { Final Sample Size } \\
\text { after Pre-Registered }\end{array}$ & $\begin{array}{l}\mathrm{T}_{1} \text { Total Sample }=346(\text { a sub-portion of } \\
\left.\text { this sample completed } \mathrm{T}_{0}\right)\end{array}$ & $\mathrm{N}=537$ & $\mathrm{~N}=259$ \\
\hline Age Demographics & $\begin{array}{l}\mathrm{T}_{1} \text { Total Sample: } M_{\text {age }}=41.51, S D_{\text {age }}=13.46 \\
\text { Sub-Sample to complete } \mathrm{T}_{0} \text { and } \mathrm{T}_{1} \text { : } \\
M_{\text {age }}=42.27, S D_{\text {age }}=13.99\end{array}$ & $M_{\text {age }}=39.25, S D_{\text {age }}=12.97$ & $M_{\text {age }}=42.17, S D_{\text {age }}=13.93$ \\
\hline $\begin{array}{l}\text { Gender } \\
\text { Demographics }\end{array}$ & $\begin{array}{l}\mathrm{T}_{1} \text { Total Sample: } 160 \text { male, } 184 \text { female, } 2 \\
\text { other } \\
\text { Sub-Sample to complete } \mathrm{T}_{0} \text { and } \mathrm{T}_{1}: 86 \\
\text { male, } 105 \text { female, } 2 \text { other }\end{array}$ & 256 male, 278 female, 3 other & 122 male, 137 female \\
\hline
\end{tabular}


Realistic and Symbolic Threats of COVID-19

\begin{tabular}{llll}
\hline Ethnic & $\mathrm{T}_{1}$ Total Sample: $80.9 \%$ White, 9.5\% Black & $77.8 \%$ White, 11.7\% Black or African & $81.9 \%$ White, 9.3\% Black or African \\
Demographics & or African American, 4.9\% & American, 5.6\% Latinx/Hispanic & American, 3.5\% Latinx/Hispanic
\end{tabular}
Latinx/Hispanic

Sub-Sample to complete $\mathrm{T}_{0}$ and $\mathrm{T}_{1}: 85.5 \%$ White, $8.8 \%$ Black or African American, $3.1 \%$ Latinx/Hispanic 


\section{Study 1}

We examined the convergent, divergent, and criterion validity of an initial item-set developed to assess perceived realistic and symbolic threat of COVID-19. Half of our sample had previously completed a survey unrelated to COVID-19 in October 2019, which allowed us to assess scale validity both cross-sectionally (analyzing all responses during COVID-19), and longitudinally (analyzing pre- and post-COVID-19 differences among the same sample).

\section{Method}

Integrated COVID-19 Threat Scale. All items (listed in Table 2) were framed with the opening: "How much of a threat, if any, is the coronavirus outbreak to..." and were rated from 1 (Not a Threat) to 4 (Major Threat). To assess realistic threat, we adapted 5 pre-existing items $(\alpha=.77)$ used by the Pew Research Poll (Pew Research Poll, Wave 63.5, March 10, 2020). We created 5 items $(\alpha=.85)$ to assess symbolic threat of COVID-19. Four items were based on Stephan and colleagues' (2009) definition of symbolic threat cited above, while one item assessed threat to the freedom of one's national group (Kachanoff, Taylor, Caouette, Khullar, \& Wohl, 2019) ${ }^{3}$.

Other Measures. All questionnaires reported are available in the Supplemental Materials and detailed in Table 3.

\section{Results}

For all studies, we provide a more detailed result summary in Supplemental Materials.

\footnotetext{
${ }^{3}$ We generated a pool of 20 items to explore different types of threat which go beyond the focus of this paper (e.g., threat to loved ones). All items are available in Supplemental Materials and OSF data. We do not focus on items pertaining to loved ones because of their substantial overlap with items pertaining to the self. We also limited the realistic threat items to only those used in the PEW poll so our findings can generalize to their report. We validated our scale structure in two subsequent pre-registered studies (Study 2 and 3) using only the 10-item scale.
} 
Factor structure of Integrated COVID-19 Threat Scale. Exploratory factor analysis using Principal Axis Factoring and Oblique Promax rotation (Carpenter, 2018; see Supplemental Materials for details) revealed a 2-factor solution: one factor with 5 items assessing symbolic threat $($ Eigen Value $=4.20)$, and one factor with 5 items assessing realistic threat $($ Eigen Value $=$ 1.64). See Table 2 for factor loadings.

Table 2. Oblique Promax rotated-factor loadings of a Principal Axis Factoring analysis of the 10-item Integrated COVID-19 Threat Scale.

\begin{tabular}{lll}
\hline How much of a threat, if any, is the coronavirus outbreak for..... & $\begin{array}{l}\text { Symbolic } \\
\text { Threat }\end{array}$ & $\begin{array}{l}\text { Realistic } \\
\text { Threat }\end{array}$ \\
\hline 1. The rights and freedoms of the U.S. population as a whole & $\mathbf{0 . 6 4}$ & 0.08 \\
2. What it means to be American & $\mathbf{0 . 8 3}$ & -0.09 \\
3. American values and traditions & $\mathbf{0 . 8 7}$ & -0.12 \\
4. American democracy & $\mathbf{0 . 6 8}$ & 0.08 \\
5. The maintenance of law and order in America & $\mathbf{0 . 5 9}$ & 0.18 \\
6. Your personal health* & 0.05 & $\mathbf{0 . 6 6}$ \\
7. The health of the U.S. population as a whole* & -0.08 & $\mathbf{0 . 8 0}$ \\
8. Your personal financial safety* & 0.17 & $\mathbf{0 . 5 1}$ \\
9. The U.S. economy* & 0.00 & $\mathbf{0 . 5 4}$ \\
10. Day-to-day life in your local community* & -0.03 & $\mathbf{0 . 6 3}$ \\
\hline
\end{tabular}

*Starred items were adapted from the Pew Research Poll, Wave 63.5, March 10, 2020. Bolding of factor loadings for each scale item indicates onto which sub-factor the scale item loaded.

\section{Cross-sectional analysis (full sample).}

Convergent and divergent validity. Indicating convergent validity (H1), perceived threat of COVID-19 was positively associated with need for cognitive closure, belief in a dangerous world, values associated with conservation, and was negatively associated with emotional stability (whether both dimensions were combined or-largely-examined independently). Indicating divergent validity (H2), threat of COVID-19 (combining both dimensions) was not significantly associated with any of the other dimensions of Schwartz's value scale or the TenItem-Personality Inventory. See Table 3 for descriptive statistics and correlations. 
Realistic and Symbolic Threats of COVID-19

Criterion validity. We examined the relation between realistic threat and symbolic threat, and psychological distress outcomes (H3) simultaneously with one structural equation model (SEM; Byrne, 1994; see Supplemental Materials for details). Realistic threat was significantly positively associated with anxiety $(b=2.79,95 \% \mathrm{CI}[1.85,3,72], p<.001)$, as well as with COVID-19 impact intrusion $(b=3.18,95 \%$ CI [2.29, 4.07], $p<.001)$, but was not associated with COVID-19 impact avoidance $(b=.25,95 \%$ CI $[-.72,1.22], p=.613)$. Symbolic threat was significantly positively associated with COVID-19 impact avoidance $(b=.98,95 \%$ CI $[.26,1.70]$, $p=.008)$ and COVID-19 impact intrusion $(b=1.10,95 \%$ CI $[.43,1.77], p=.001)$, but was not significantly associated with anxiety $(b=.56,95 \%$ CI $[-.14,1.26], p=.114)$. 
Realistic and Symbolic Threats of COVID-19

Table 3. Correlations between COVID-19 Threat and All Measures Assessed at During the COVID-19 Outbreak (N=346; Study 1).

\begin{tabular}{|c|c|c|c|c|c|c|c|}
\hline Variables & & $\begin{array}{l}\text { COVID-19 } \\
\text { Threat - } \\
\text { Full Scale }\end{array}$ & $\begin{array}{l}\text { COVID-19 } \\
\text { Threat - } \\
\text { Realistic }\end{array}$ & $\begin{array}{l}\text { COVID-19 } \\
\text { Threat - } \\
\text { Symbolic }\end{array}$ & Mean & $\mathrm{SD}$ & Reliability \\
\hline \multicolumn{8}{|c|}{$\begin{array}{l}\text { Convergent } \\
\text { Validity }\end{array}$} \\
\hline & COVID-19 Threat - Full Scale & & & & 2.74 & 0.59 & $\alpha=.85$ \\
\hline & COVID-19 Threat - Realistic & $.80^{* * *}$ & & & 3.21 & 0.59 & $\alpha=.77$ \\
\hline & COVID-19 Threat - Symbolic & $.89^{* * *}$ & $.45^{* * *}$ & & 2.28 & 0.79 & $\alpha=.85$ \\
\hline & Need for Cognitive Closure (Webster \& Kruglanski, 1998) & $.20^{* * *}$ & $.16^{* *}$ & $.18^{* * *}$ & 3.97 & 0.84 & $\alpha=.89$ \\
\hline & Belief in a Dangerous World (Altemeyer, 1988) & $.30^{* * *}$ & $.21^{* * *}$ & $.30^{* * *}$ & 4.06 & 1.32 & $\alpha=.93$ \\
\hline & Schwartz Values - Conservation (Stern, Dietz, \& Guagnano, 1998) & $.23^{* * *}$ & .043 & $.31^{* * *}$ & 4.28 & 1.48 & $\alpha=.65$ \\
\hline & TIPI - Emotional Stability (Gosling, Rentfrow, \& Swann, 2003) & $-.18^{* * *}$ & $-.21^{* * *}$ & $-.11^{*}$ & 4.93 & 1.58 & $r=.41$ \\
\hline \multicolumn{8}{|l|}{$\begin{array}{l}\text { Divergent } \\
\text { Validity }\end{array}$} \\
\hline & $\begin{array}{l}\text { Schwartz Values- Openness to Change (Stern, Dietz, \& Guagnano, } \\
\text { 1998) }\end{array}$ & 0.08 & 0.06 & 0.07 & 5.17 & 1.29 & $r=.23$ \\
\hline & $\begin{array}{l}\text { Schwartz Values- Self Enhancement (Stern, Dietz, \& Guagnano, } \\
\text { 1998) }\end{array}$ & 0.08 & -0.01 & $.12^{*}$ & 3.69 & 1.40 & $\alpha=.58$ \\
\hline & $\begin{array}{l}\text { Schwartz Values- Self Transcendence (Stern, Dietz, \& Guagnano, } \\
\text { 1998) }\end{array}$ & 0.06 & 0.10 & 0.01 & 4.57 & 1.74 & $r=.33$ \\
\hline & $\begin{array}{l}\text { TIPI - Openness to Experiences (Gosling, Rentfrow, \& Swann, } \\
\text { 2003) }\end{array}$ & -0.03 & -0.02 & -0.03 & 5.25 & 1.31 & $r=.46$ \\
\hline & TIPI - Extraversion (Gosling, Rentfrow, \& Swann, 2003) & -0.02 & -0.06 & 0.02 & 3.49 & 1.80 & $r=.69$ \\
\hline & TIPI - Agreeableness (Gosling, Rentfrow, \& Swann, 2003) & 0.01 & 0.02 & 0.01 & 5.54 & 1.16 & $r=.31$ \\
\hline & TIPI - Conscientiousness (Gosling, Rentfrow, \& Swann, 2003) & 0.04 & 0.02 & 0.05 & 5.65 & 1.17 & $r=.49$ \\
\hline \multicolumn{8}{|l|}{$\begin{array}{l}\text { Criterion } \\
\text { Validity }\end{array}$} \\
\hline & Anxiety (During COVID-19) (Beck, Epstein, Brown, \& Steer, 1988) & $.34^{* * *}$ & $.37^{* * *}$ & $.24^{* *}$ & 5.91 & 5.06 & $\alpha=.87$ \\
\hline & COVID-19 Impact Intrusion (Horowitz, Wilner, \& Alverez, 1979) & $.45^{* * *}$ & $.45^{* *}$ & $.34^{* * *}$ & 7.15 & 5.09 & $\alpha=.87$ \\
\hline & COVID-19 Impact Avoidance (Horowitz, Wilner, \& Alverez, 1979) & $.17^{* *}$ & 0.10 & $.17^{* *}$ & 7.32 & 4.92 & $\alpha=.81$ \\
\hline
\end{tabular}




\section{Longitudinal evidence (repeat participants only).}

Convergent and divergent validity. See Table 4 for descriptive statistics and correlations. Indicating convergent validity (H1), and replicating our cross-sectional results, the perceived threat of COVID-19 was positively associated with all four individual differences associated with threat sensitivity (whether both dimensions were combined or-largelyexamined independently). Indicating divergent validity (H2), threat of COVID-19 was largely not associated with other values or personality traits.

Criterion validity. Providing partial support for $\mathrm{H} 3$, realistic threat $(b=1,71,95 \% \mathrm{CI}[.67$, $2.75], p=.001)$ but not symbolic threat $(b=.28,95 \%$ CI $[-.50,1.06], p=.486)$ was associated with anxiety during the pandemic, controlling for base-line anxiety.

\section{Discussion}

We found initial support in Study 1 for the factorial structure, as well as for the convergent and divergent validity of our scale. The threat of COVID-19 was robustly associated with individual differences linked to threat sensitivity (supporting H1), but COVID-19 threat was not consistently associated with other personality traits or universal values (supporting H2). Demonstrating criterion validity, both realistic and symbolic threat were both uniquely related to psychological distress (supporting H3). Realistic threat was robustly associated with having intrusive thoughts about the virus, and heightened anxiety (even when controlling for anxiety five months prior). Symbolic threat (but not realistic threat) was associated with trying to avoid thinking about or dealing with the virus, as well as, intrusive thoughts. We further tested the validity of our scale in Study 2 and examined whether/how realistic or symbolic threat predict socially restrictive public health behaviors. 
Realistic and Symbolic Threats of COVID-19

Table 4. Correlations between COVID-19 Threat at Time 1 and All Measures Assessed at Time 0 (N=193; Study 1)

\begin{tabular}{|c|c|c|c|c|c|c|c|}
\hline Variables & & $\begin{array}{l}\text { COVID-19 } \\
\text { Threat - Full } \\
\text { Scale }\end{array}$ & $\begin{array}{l}\text { COVID-19 } \\
\text { Threat - } \\
\text { Realistic }\end{array}$ & $\begin{array}{l}\text { COVID-19 } \\
\text { Threat - } \\
\text { Symbolic }\end{array}$ & Mean & SD & Reliability \\
\hline \multirow{2}{*}{\multicolumn{8}{|c|}{ Convergent }} \\
\hline & & & & & & & \\
\hline & $\begin{array}{l}\text { Need for Cognitive Closure (Before } \\
\text { COVID-19) }\end{array}$ & $.26^{* * *}$ & $.20^{* *}$ & $.24^{* * *}$ & 3.92 & 0.89 & $\alpha=.90$ \\
\hline & $\begin{array}{l}\text { Belief in a Dangerous World (Before } \\
\text { COVID-19) }\end{array}$ & $.31^{* * *}$ & $.23^{* *}$ & $.30^{* * *}$ & 4.13 & 1.32 & $\alpha=.92$ \\
\hline & $\begin{array}{l}\text { Schwartz Values - Conservation } \\
\text { (Before COVID-19) }\end{array}$ & $.168^{*}$ & .06 & $.21^{* *}$ & 4.13 & 1.45 & $\alpha=.63$ \\
\hline & $\begin{array}{l}\text { TIPI - Emotional Stability (Before } \\
\text { COVID-19) }\end{array}$ & $-.23^{* * *}$ & $-.24^{* * *}$ & $-.16^{*}$ & 4.89 & 1.64 & $r=.69$ \\
\hline \multicolumn{8}{|l|}{$\begin{array}{l}\text { Divergent } \\
\text { Validity }\end{array}$} \\
\hline & $\begin{array}{l}\text { Schwartz Values - Openness to } \\
\text { Change (Before COVID-19) }\end{array}$ & .07 & .04 & .07 & 5.18 & 1.34 & $r=.28$ \\
\hline & $\begin{array}{l}\text { Schwartz Values - Self } \\
\text { Enhancement (Before COVID-19) }\end{array}$ & $.19^{* *}$ & $.15^{*}$ & $.17^{*}$ & 3.46 & 1.26 & $\alpha=.44$ \\
\hline & $\begin{array}{l}\text { Schwartz Values - Self } \\
\text { Transcendence (Before COVID-19) }\end{array}$ & $.14^{\dagger}$ & $.23^{* * *}$ & .03 & 4.35 & 1.59 & $r=.13$ \\
\hline & $\begin{array}{l}\text { TIPI - Openness to Experiences } \\
\text { (Before COVID-19) }\end{array}$ & -.08 & -.02 & -.11 & 5.21 & 1.42 & $r=.52$ \\
\hline & $\begin{array}{l}\text { TIPI - Extraversion (Before COVID- } \\
\text { 19) }\end{array}$ & .03 & -.03 & .07 & 3.33 & 1.79 & $r=.70$ \\
\hline & $\begin{array}{l}\text { TIPI - Agreeableness (Before } \\
\text { COVID-19) }\end{array}$ & .03 & .00 & .04 & 5.58 & 1.10 & $r=.18$ \\
\hline & $\begin{array}{l}\text { TIPI - Conscientiousness (Before } \\
\text { COVID-19) }\end{array}$ & -.02 & -.07 & .03 & 5.72 & 1.17 & $r=.51$ \\
\hline
\end{tabular}

${ }^{t} p<.10, * p=.05, * * p=.01, * * * p=.001$ 


\section{Study 2}

We sought to fully replicate Study 1 which provided support for H1-H3. With regard to H3, we also assessed psychological well-being (Diener, et al., 1985) and affect (Watson, et al., 1988) to broaden the scope of Study 1 which was limited to psychological distress outcomes. In addition, we tested (H4) whether realistic and symbolic threat might be inversely related to selfreported support and adherence to socially restrictive public health behaviors (i.e., social distancing) but not non-restrictive public health behaviors (i.e., handwashing). Lastly, we tested (H5) whether symbolic threat related to finding new ways to maintain social (national) identity in isolation.

\section{Method}

Measures. All questionnaires reported are available in the Supplemental Materials and are detailed in Table 6. In Table 5 we provide all items used to assess compliance with public health behaviors and social identity affirmation in isolation.

Table 5. Items used to measure attitudinal and behavioral responses to COVID-19 (Study 2).

(R) indicates reversed-scored items.

$$
\text { Scale }
$$
Items

\section{Adherence to Socially Restrictive Public}

Health (CDC) Behaviors (adapted from

Everett et al., 2020; 1 = "Not at all" to 5

$=$ "Always" scale; $r=.54$ )

1. Avoiding public gatherings.

2. Staying at home and avoiding all social contact 
Realistic and Symbolic Threats of COVID-19

Everett et al., 2020; 1 = "Not at all" to 5

$=$ "Always" scale)

1. Washing your hands often for at least 20 seconds especially after being in a public place.

Support for Socially Restrictive Public

Health Behaviors to Reduce Spread of

COVID-19 (1 = "Strongly disagree" to

$7=$ "Strongly agree" scale; $\alpha=.89$ )

Social (National) Identity Affirming

Behaviors in Isolation $(1=$ "Not at all"

to $5=$ "Always" scale; $\alpha=.79$ )

1. The social distancing restrictions being put into place to stop the spread of Covid-19 are doing more harm than good. (R)

2. We need to prioritize going back to our normal routines as soon as possible, regardless of COVID-19's spread. (R)

3. Right now the most important thing we can do is take all measures possible to stop the spread of COVID-19.

4. It is essential that we strictly practice social distancing as a nation, until health care experts say otherwise.

1. I watch or listen to music, videos, movies, or re-plays of cultural events that remind me most of American culture.

2. I share things with my friends and family on the phone or through social media that remind us of what life was like in America before COVID-19.

3. I engage in behaviors that I associate with American identity (e.g., I cook foods that make me feel American).

Identity-Non-Specific Social Behaviors

in Isolation $(1=$ "Not at all" to $5=$ "Always" scale; $r=.47$ )

1. I find creative new ways to maintain my old routines (e.g., video chats with family and friends; online exercise classes; cultural activities online).

2. I engage with "virtual communities" through social media and online groups to replace the in-person communities I can no longer be a part of. 
Realistic and Symbolic Threats of COVID-19

\section{Results}

Confirmatory factor analysis. Confirmatory factor analysis (CFA; Byrne, 1994) indicated the two-factor model had acceptable model fit indices: comparative fit index $(C F I)=.94$, standard root mean square residuals $(S R M R)=.06$, root mean square error approximation $(R M S E A)=.08,90 \% \mathrm{CI}[.07, .09], B I C=11852.71, \chi^{2}=144.03(\mathrm{Hu} \&$ Bentler, 1999; Byrne, 1994; Steiger, 1990) and no negative error variances or improper solutions, see Figure 2. The two-factor model had superior fit $\left(\chi_{\text {dif }}^{2}=-352.60, p<.001\right)$ relative to a one-factor model which did not differentiate between realistic or symbolic threat $(C F I=.75, S R M R=.12$, RMSEA $\left.=.16,90 \% \mathrm{CI}[.15, .17], B I C=12199.03, \chi^{2}=496.63\right)$.

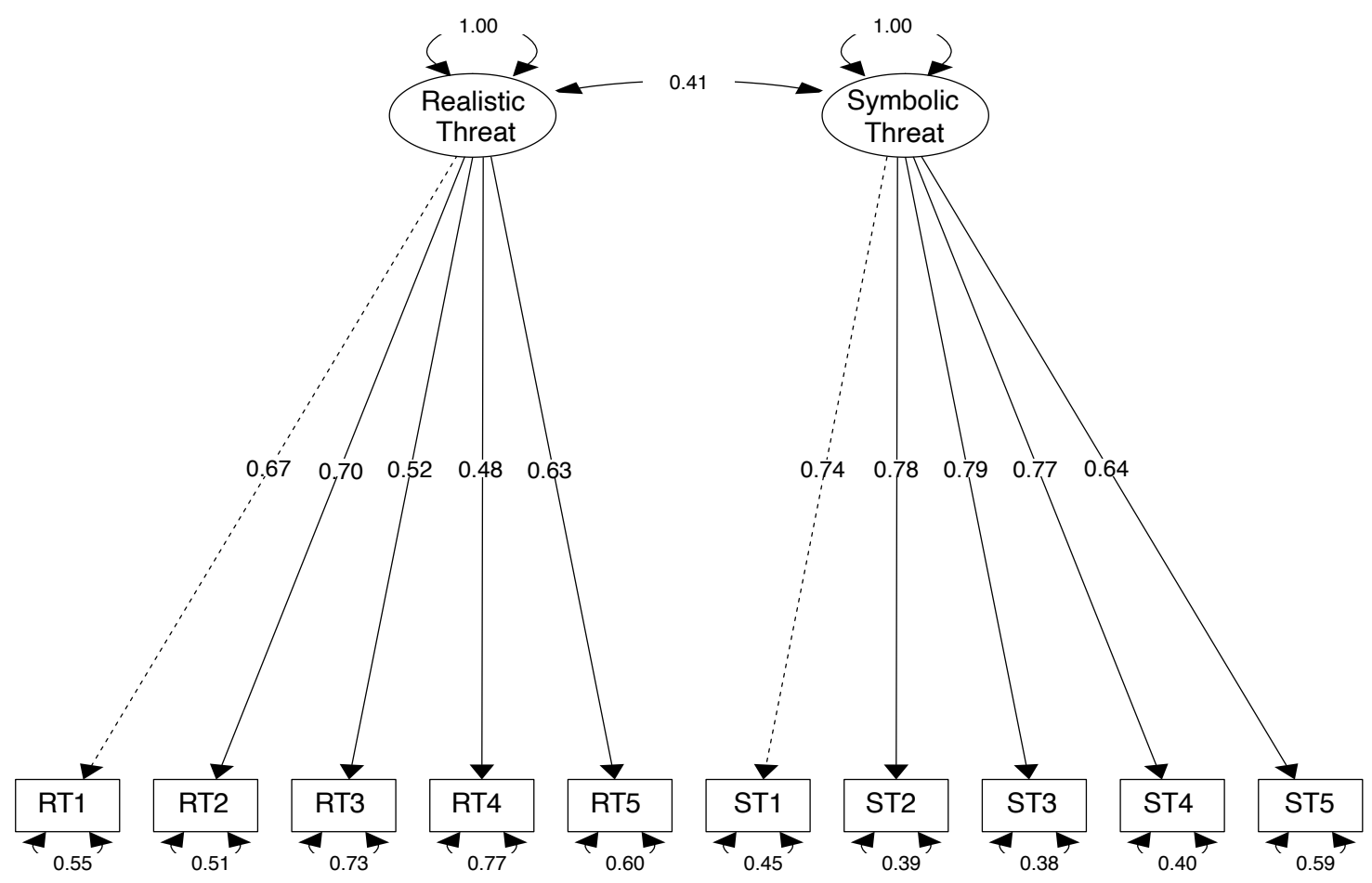

Figure 2. Confirmatory Factor Analysis testing the predicted 2-factor structure of the 10-Item Integrated COVID-19 Threat Scale (Study 2) 
Realistic and Symbolic Threats of COVID-19

Table 6. Descriptives, reliability, and Pearson's Correlations for Variables Pertaining to Convergent and Divergent Validity (Study 2)

\begin{tabular}{|c|c|c|c|c|c|c|c|}
\hline Variables & & $\begin{array}{l}\text { COVID-19 } \\
\text { Threat - } \\
\text { Full Scale }\end{array}$ & $\begin{array}{l}\text { COVID-19 } \\
\text { Threat- } \\
\text { Realistic }\end{array}$ & $\begin{array}{l}\text { COVID-19 } \\
\text { Threat - } \\
\text { Symbolic }\end{array}$ & Mean & $\mathrm{SD}$ & Reliability \\
\hline \multicolumn{8}{|c|}{ Convergent } \\
\hline Validity & & & & & & & \\
\hline & COVID-19 Threat - Full Scale & & & & 2.80 & 0.55 & $\alpha=.83$ \\
\hline & COVID-19 Threat - Realistic & $.75^{* * *}$ & & & 3.24 & 0.54 & $\alpha=.73$ \\
\hline & COVID-19 Threat - Symbolic & $.89^{* * *}$ & $.37^{* * *}$ & & 2.37 & 0.77 & $\alpha=.86$ \\
\hline & Need for Cognitive Closure & $.20^{* * *}$ & $.17^{* * *}$ & $.17^{* * *}$ & 3.99 & 0.82 & $\alpha=.89$ \\
\hline & Belief in a Dangerous World & $.38^{* * *}$ & $.20^{* * *}$ & $.39^{* * *}$ & 3.80 & 1.28 & $\alpha=.89$ \\
\hline & Schwartz Values -Conservation & $.16^{* * *}$ & .08 & $.18^{* * *}$ & 4.36 & 1.47 & $\alpha=.92$ \\
\hline & TIPI- Emotional Stability & $-.16^{* * *}$ & $-.17^{* * *}$ & $-.11^{*}$ & 4.97 & 1.51 & $r=.64$ \\
\hline \multicolumn{8}{|l|}{$\begin{array}{l}\text { Divergent } \\
\text { Validity }\end{array}$} \\
\hline Validity & $\begin{array}{l}\text { Schwartz Values - Openness to } \\
\text { Change }\end{array}$ & .08 & .06 & $.08^{\dagger}$ & 5.26 & 1.37 & $r=.29$ \\
\hline & $\begin{array}{l}\text { Schwartz Values- Self } \\
\text { Enhancement }\end{array}$ & $.10^{*}$ & .02 & $.13^{* * *}$ & 3.85 & 1.44 & $\alpha=.59$ \\
\hline & $\begin{array}{l}\text { Schwartz Values - Self } \\
\text { Transcendence }\end{array}$ & $.08^{\dagger}$ & $.16^{* * *}$ & .01 & 4.44 & 1.56 & $r=.20$ \\
\hline & TIPI - Openness to Experiences & -.06 & .02 & $-.10^{*}$ & 5.20 & 1.21 & $r=.37$ \\
\hline & TIPI - Extraversion & -.05 & -.06 & -.02 & 3.51 & 1.66 & $r=.64$ \\
\hline & TIPI - Agreeableness & -.01 & $.09^{*}$ & $-.08^{t}$ & 5.36 & 1.29 & $r=.39$ \\
\hline & TIPI - Conscientiousness & -.01 & .01 & -.01 & 5.61 & 1.25 & $r=.52$ \\
\hline
\end{tabular}

${ }^{\dagger} p<.10, * p=.05, * * p=.01, * * * p=.001$ 
Realistic and Symbolic Threats of COVID-19

Convergent and divergent validity. Overall, results were consistent with Study 1, supporting both convergent $(\mathrm{H} 1)$ and divergent $(\mathrm{H} 2)$ validity. See Table 6 for descriptives and correlations and Supplemental Materials for full description of results.

\section{Criterion validity.}

Table 7 summarizes descriptives for all criterion outcomes as well as their zero-order correlations with COVID-19 threat. As in Study 1, we assessed the association between realistic threat and symbolic threat, and all criterion outcomes simultaneously within one SEM model (See Table 8). All results described below refer to relations observed in the full SEM model.

Psychological distress, well-being, and affect (H3). Replicating Study 1, realistic threat was significantly positively associated with anxiety and COVID-19 impact intrusion, while symbolic threat was significantly positively associated with COVID-19 impact avoidance and COVID-19 impact intrusion. In contrast to Study 1, realistic threat was also associated with COVID-19 impact avoidance, while symbolic threat was also significantly associated with anxiety.

Providing partial support for $\mathrm{H} 3$, realistic (but not symbolic) threat was negatively associated with life satisfaction. Symbolic and realistic threat were positively associated with negative affect. We observed an unanticipated significant positive relation between symbolic threat and positive affect. Exploratory parallel-mediation analysis revealed this effect was partially mediated by increased social (national) identity affirming behaviors in isolation, but not decreased adherence to socially restrictive public health behaviors; See analysis in Supplemental Materials for details).

\section{Support and adherence with socially restrictive and non-restrictive public health}

behaviors (H4). Realistic threat was significantly and positively associated with support of and 
Realistic and Symbolic Threats of COVID-19

self-reported adherence to socially restrictive public health behaviors (i.e., social distancing) and non-restrictive health behaviors (i.e., handwashing). In contrast, symbolic threat was significantly and negatively associated with support and adherence to socially restrictive public health behaviors, and was unrelated to non-restrictive health behaviors.

Social (national) identity affirmation in isolation (H5). Symbolic (but not realistic) threat was positively associated with engaging in behaviors (while in isolation) to affirm one's (national) identity (e.g., cooking food subjectively associated with America). In contrast, realistic threat (but not symbolic threat) was associated with engagement in identity-non-specific social behaviors which were routine prior to the pandemic (e.g., communication with family, exercise groups, or local communities). 
Realistic and Symbolic Threats of COVID-19

Table 7. Descriptives and Pearson's Correlations for Criterion Outcomes (Study 2)

\begin{tabular}{|c|c|c|c|c|c|c|}
\hline Variables & $\begin{array}{l}\text { COVID-19 } \\
\text { Threat - } \\
\text { Full Scale }\end{array}$ & $\begin{array}{l}\text { COVID-19 } \\
\text { Threat- } \\
\text { Realistic }\end{array}$ & $\begin{array}{l}\text { COVID-19 } \\
\text { Threat - } \\
\text { Symbolic }\end{array}$ & Mean & SD & Reliability \\
\hline Anxiety & $.36^{* * *}$ & $.37^{* * *}$ & $.25^{* * *}$ & 6.07 & 5.38 & $\alpha=.89$ \\
\hline COVID-19 - Impact Intrusion & $.40^{* * *}$ & $.43^{* * *}$ & $.27^{* * *}$ & 6.80 & 4.92 & $\alpha=.86$ \\
\hline COVID-19 - Impact Avoidance & $.21^{* * *}$ & $.18^{* * *}$ & $.18^{* * *}$ & 7.72 & 4.87 & $\alpha=.79$ \\
\hline $\begin{array}{l}\text { Life Satisfaction (Diener, Emmons, } \\
\text { Larsen, Griffin, 1985) }\end{array}$ & $-.15^{* *}$ & $-.17^{* * *}$ & $-.09^{*}$ & 4.23 & 1.49 & $\alpha=.89$ \\
\hline $\begin{array}{l}\text { Positive Affect (Watson, Clark, \& } \\
\text { Tellegen, 1988) }\end{array}$ & .06 & -.03 & $.10^{*}$ & 27.63 & 8.45 & $\alpha=.91$ \\
\hline $\begin{array}{l}\text { Negative Affect (Watson, Clark, \& } \\
\text { Tellegen, 1988) }\end{array}$ & $.36^{* * *}$ & $.32^{* * *}$ & $.28^{* * *}$ & 17.40 & 7.89 & $\alpha=.92$ \\
\hline $\begin{array}{l}\text { Adherence to Socially Restrictive } \\
\text { (CDC) Public Health Behaviors } \\
\text { (Everett et al., 2020) }\end{array}$ & $.11^{*}$ & $.28^{* * *}$ & -.04 & 4.50 & .63 & $r=.54$ \\
\hline $\begin{array}{l}\text { Adherence to Non-Restrictive } \\
\text { (CDC) Public Health Behaviors } \\
\text { (Everett et al., 2020) }\end{array}$ & $.17^{* * *}$ & $.28^{* * *}$ & .05 & 4.52 & .77 & - \\
\hline $\begin{array}{l}\text { Support for Socially Restrictive } \\
\text { Public Health Behaviors to Reduce } \\
\text { Spread of COVID-19 }\end{array}$ & .03 & $.35^{* * *}$ & $-.20^{* * *}$ & 5.97 & 1.32 & $\alpha=.89$ \\
\hline $\begin{array}{l}\text { Social (National) Identity } \\
\text { Affirming Behaviors in Isolation }\end{array}$ & $.20^{* * *}$ & $.14^{* *}$ & $.20^{* * *}$ & 2.61 & 1.09 & $\alpha=.79$ \\
\hline $\begin{array}{l}\text { Identity Non-Specific Social } \\
\text { Behaviors in Isolation }\end{array}$ & $.09^{*}$ & $.15^{* *}$ & .02 & 3.06 & 1.05 & $r=.47$ \\
\hline
\end{tabular}

${ }^{\dagger} p<.10, * p=.05, * * p=.01, * * * p=.001$ 
Realistic and Symbolic Threats of COVID-19

Table 8. Symbolic and realistic threat of the COVID-19 virus in relation to criterion outcomes (Study 2; data collected on March 26, 2020).

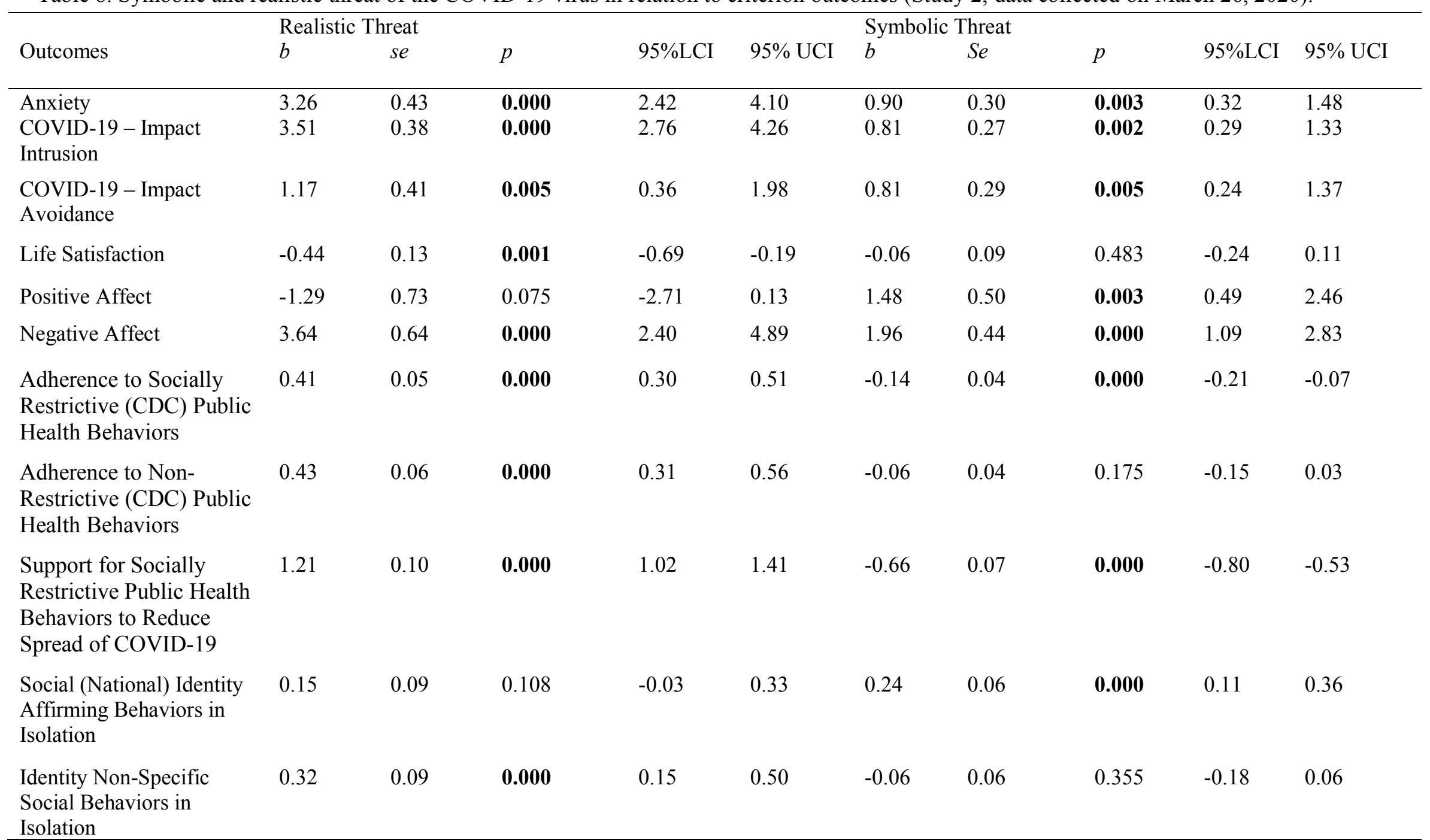

Note. $b$ values reflect non-standardized path estimates from one SEM model including all measured variables simultaneously. Realistic and Symbolic Threat were covaried in the model. All outcomes were covaried with each other in the model. Bolding indicates significance. 
Realistic and Symbolic Threats of COVID-19

\section{Discussion}

Study 2 further suggested that realistic threat and symbolic threat are two distinct forms of COVID-19 threat (using CFA), and replicated Study 1 findings pertaining to convergent (H1) and divergent (H2) validity. Both threats were consequential. Supporting H3, people who experienced greater realistic and symbolic threat reported greater psychological distress and negative affect. Realistic threat was also associated with less life-satisfaction and positive affect.

Realistic and symbolic threats oppositely predicted support and engagement with socially restrictive public health behaviors $(\mathrm{H} 4)$. People higher in realistic threat reported more adherence/support for social distancing, while people higher in symbolic threat reported less adherence/support. Realistic threat also predicted self-reported hand-washing, while symbolic threat was unrelated to this behavior. As predicted, experiencing symbolic threat was positively associated with engaging in social (national) identity affirming behaviors in social isolation (e.g., consuming food, music, or media associated with national identity). Realistic threat was related to engaging in social behaviors (virtually) that were less directly tied to social identity (e.g., seeing friends or engaging in online fitness classes), presumably because individuals high in realistic threat were spending more time in isolation.

\section{Study 3}

In Study 3 we aimed to replicate Study 2's findings pertaining to criterion outcomes (i.e., $\mathrm{H} 3, \mathrm{H} 4$, and H5), using a longitudinal design in which we examined whether perceived threat of COVID-19 predicted outcomes one week later. To do this, we re-sampled as many participants who took part in Study 1 (Time 1: March $19^{\text {th }}-20^{\text {th }}$ ) as possible and asked them to complete criterion measures one week later (Time 2: March $27^{\text {th }}-28^{\text {th }}$ ). In addition, we asked participants to 
Realistic and Symbolic Threats of COVID-19

complete the ten-item COVID-19 threat scale at the end of the survey, so we could test the longitudinal invariance of the scale.

\section{Method}

Measures. We assessed realistic and symbolic threat and all criterion validity measures used in Study 2. See Tables 10 for reliability and the Supplemental Materials for the full questionnaires.

\section{Results}

Scale invariance. We examined the invariance of both subscales using longitudinal confirmatory factor analysis (Meredith, 1993; see Supplemental Materials for details). Because we confirmed two distinct factors in Study 2, and because our analyses focus on the separate sub-scales, we explored invariance of each sub-scale separately. We found evidence of configural invariance (i.e., the scale assessed the same construct over time), metric invariance (i.e., the scale had the same meaning over time), scalar invariance (i.e., it is valid to compare means over time) and that the means were equivalent over time (see Table 9; all $\Delta X^{2}$ n.s ; all $\Delta$ CFIs did not indicate fit deterioration $>-.01$; all $\triangle$ RMSEAs did $<.015$; Chen, 2007; Byrne, Shavelson, \& Muthén, 1989).

\section{Criterion validity.}

Table 10 summarizes descriptives for all criterion outcomes (T2) as well as their zeroorder correlations with COVID-19 threat assessed at T1. Using SEM, we examined the association between realistic threat and symbolic threat (at T1), and all criterion outcomes assessed one week later (at T2), simultaneously in one model (Table 11). All results described below refer to relations observed in the full SEM model. 
Realistic and Symbolic Threats of COVID-19

Psychological distress, well-being, and affect (H3). Realistic threat (at T1) was associated with COVID-19 impact intrusion and anxiety, but was not associated with COVID-19 impact avoidance, over the course of the following week (measured at T2). Symbolic threat was also significantly positively associated with COVID-19 impact intrusion, general anxiety, and additionally, impact avoidance.

Both types of threat (at T1) were positively associated with negative affect experienced over the course of a subsequent week. Replicating Study 2, realistic threat (but not symbolic threat) was negatively associated with life satisfaction. As in Study 2, we again observed an unanticipated significant positive relation between symbolic threat and positive affect. Exploratory parallel-mediation analysis showed this effect was mediated by increases in social (national) identity affirming behaviors in isolation but not decreased adherence to socially restrictive public health behaviors.

\section{Support and adherence to socially restrictive and non-restrictive public health}

behaviors (H4). Replicating Study 2, experiencing realistic threat (at T1) was significantly and positively associated with support and adherence with socially restrictive public health behaviors to fight COVID-19 over the course of the subsequent week (assessed at T2). In direct contrast, experiencing symbolic threat was significantly and negatively associated with support and adherence. Realistic threat also predicted adherence to non-restrictive public health behaviors (hand-washing) over the week, while symbolic threat was marginally negatively related.

Social identity affirmation in isolation (H5). Replicating Study 2, symbolic (but not realistic) threat at T1 was positively associated with self-reported engagement in behaviors (while in isolation) to affirm one's (national) identity over the course of the next week. Unlike 
Study 2, we did not observe an association between realistic threat and virtual engagement in identity-non-specific social behaviors ${ }^{4}$.

\section{Discussion}

Both dimensions of the 10-item threat scale were invariant when re-assessed one week later, suggesting that the scale can be used to compare changes in perceived threat over time (Flake et al., 2017). Consistent with Study 1-2, and supporting H3, both threats were uniquely associated with greater psychological distress and more negative affect one week later (with some nuance in terms of which distress outcomes were impacted). Realistic threat was also associated with reduced well-being and less positive affect. Supporting H4, realistic threat predicted greater support and self-reported adherence to socially restrictive health behaviors, while symbolic threat predicted diminished adherence and support. Realistic (but not symbolic) threat also predicted self-reported adherence to non-restrictive health behaviors (i.e., hand washing). Supporting H5, symbolic threat (but not realistic threat) was associated with engaging in behaviors while in social isolation that directly affirm social (National) identity.

\footnotetext{
${ }^{4}$ In all studies participants rated their political views from 1 (extremely conservative) to 7 (extremely liberal). Across studies, total threat was not related to political ideology; symbolic threat was weakly and inconsistently positively associated with conservatism and; realistic threat was consistently negatively associated with conservatism. We repeated the SEM analyses assessing criterion outcomes, including political orientation as a predictor. Study 2 results were consistent except: the positive association between positive affect and symbolic threat became nonsignificant; realistic threat became significantly associated with social (national) identity affirmation. In Study 3, results remained consistent except the relation between life-satisfaction and realistic threat became marginal, and the negative relation between symbolic threat and adherence to socially restrictive health behaviors became non-significant (but trended in the predicted negative direction). See Supplemental Materials for details.
} 
Realistic and Symbolic Threats of COVID-19

Table 9. Longitudinal invariance analysis testing invariance of the Integrated COVID-19 Threat Sub-Scales across time (1 week).

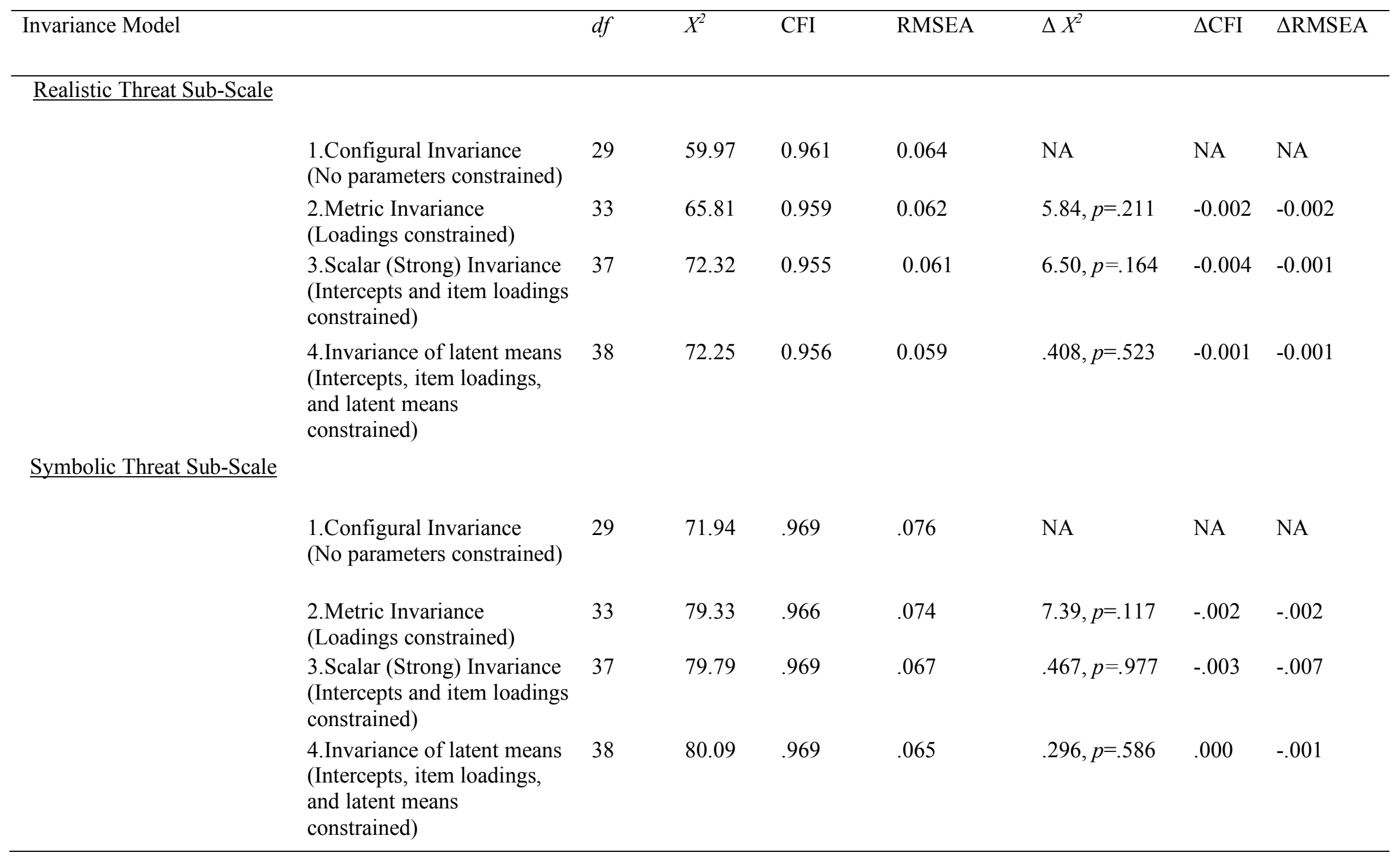


Realistic and Symbolic Threats of COVID-19

Table 10. Descriptives and Pearson's Correlations of COVID-19 Threat at T1 and Criterion Outcomes at T2 one week later (Study 3)

\begin{tabular}{|c|c|c|c|c|c|c|}
\hline Variables & $\begin{array}{l}\text { COVID- } \\
19 \text { Threat } \\
\text { - Full } \\
\text { Scale } \\
\text { (T1) }\end{array}$ & $\begin{array}{l}\text { COVID-19 } \\
\text { Threat- } \\
\text { Realistic } \\
\text { (T1) }\end{array}$ & $\begin{array}{l}\text { COVID-19 } \\
\text { Threat - } \\
\text { Symbolic } \\
\text { (T1) }\end{array}$ & Mean & SD & Reliability \\
\hline COVID-19 Threat - Full Scale (T1) & & & & 2.73 & 0.58 & $\alpha=.84$ \\
\hline COVID-19 Threat - Realistic (T1) & $.78^{* * *}$ & & & 3.20 & 0.58 & $\alpha=.75$ \\
\hline COVID-19 Threat - Symbolic (T1) & $.89^{* * *}$ & $.42^{* * *}$ & & 2.26 & 0.80 & $\alpha=.86$ \\
\hline Anxiety (T2) & $.38^{* * *}$ & $.37^{* * *}$ & $.29^{* * *}$ & 5.61 & 5.26 & $\alpha=.89$ \\
\hline COVID-19 - Impact Intrusion (T2) & $.38^{* * *}$ & $.37^{* * *}$ & $.29^{* * *}$ & 6.65 & 5.38 & $\alpha=.90$ \\
\hline COVID-19 - Impact Avoidance (T2) & $.14^{*}$ & .08 & $.15^{*}$ & 7.67 & 5.03 & $\alpha=.81$ \\
\hline Life Satisfaction (T2) & -.05 & $-.12^{\dagger}$ & .02 & 4.34 & 1.59 & $\alpha=.91$ \\
\hline Positive Affect (T2) & .02 & -.12 & 0.11 & 28.67 & 8.28 & $\alpha=.91$ \\
\hline Negative Affect (T2) & $.38^{* * *}$ & $.36^{* * *}$ & $.30^{* * *}$ & 19.52 & 8.35 & $\alpha=.92$ \\
\hline $\begin{array}{l}\text { Adherence to Socially Restrictive } \\
\text { (CDC) Public Health Behaviors (T2) }\end{array}$ & .05 & $.17^{* *}$ & -.05 & 4.59 & .58 & $r=.63$ \\
\hline $\begin{array}{l}\text { Adherence to Non-Restrictive (CDC) } \\
\text { Public Health Behaviors (T2) }\end{array}$ & $.14^{*}$ & $.26^{* * *}$ & .01 & 4.59 & .67 & - \\
\hline $\begin{array}{l}\text { Support for Socially Restrictive } \\
\text { Public Health Behaviors to Reduce } \\
\text { Spread of COVID-19 (T2) }\end{array}$ & $.11^{\dagger}$ & $.34^{* * *}$ & -.10 & 6.08 & 1.21 & $\alpha=.89$ \\
\hline $\begin{array}{l}\text { Social (National) Identity Affirming } \\
\text { Behaviors in Isolation (T2) }\end{array}$ & $.27^{* * *}$ & $.12^{\dagger}$ & $.31^{* * *}$ & 2.68 & 1.15 & $\alpha=.81$ \\
\hline $\begin{array}{l}\text { Identity Non-Specific Social } \\
\text { Behaviors in Isolation (T2) }\end{array}$ & .10 & .05 & $.12^{\dagger}$ & 3.14 & 1.04 & $r=.45$ \\
\hline COVID-19 Threat - Full Scale (T2) & $.60^{* * *}$ & $.48^{* * *}$ & $.53^{* * *}$ & 2.73 & 0.58 & $\alpha=.85$ \\
\hline COVID-19 Threat - Realistic (T2) & $.49^{* * *}$ & $.64^{* * *}$ & $.23^{* * *}$ & 3.18 & 0.54 & $\alpha=.76$ \\
\hline COVID-19 Threat - Symbolic (T2) & $.51^{* * *}$ & $.25^{* * *}$ & $.57^{* * *}$ & 2.28 & 0.82 & $\alpha=.86$ \\
\hline
\end{tabular}


Realistic and Symbolic Threats of COVID-19

Table 11. Symbolic and realistic COVID-19 threat on March 20,2020 predicting criterion outcomes on March 27, 2020 (Study 3)

\begin{tabular}{|c|c|c|c|c|c|c|c|c|c|c|}
\hline \multirow[b]{2}{*}{ Outcomes } & \multicolumn{3}{|c|}{ Realistic Threat (T1) } & \multirow[b]{2}{*}{$95 \% \mathrm{LCI}$} & \multirow[b]{2}{*}{$95 \% \mathrm{UCI}$} & \multicolumn{3}{|c|}{ Symbolic Threat (T1) } & \multirow[b]{2}{*}{$95 \% \mathrm{LCI}$} & \multirow[b]{2}{*}{$95 \% \mathrm{UCI}$} \\
\hline & $b$ & se & $p$ & & & $b$ & se & $p$ & & \\
\hline Anxiety (T2) & 2.67 & 0.56 & 0.000 & 1.57 & 3.78 & 1.12 & 0.41 & 0.007 & 0.31 & 1.93 \\
\hline COVID-19 - Impact Intrusion (T2) & 0.39 & 0.08 & 0.000 & 0.23 & 0.55 & 0.16 & 0.06 & 0.006 & 0.05 & 0.28 \\
\hline COVID-19 - Impact Avoidance (T2) & 0.02 & 0.07 & 0.826 & -0.13 & 0.16 & 0.11 & 0.05 & 0.033 & 0.01 & 0.22 \\
\hline Life Satisfaction (T2) & -0.42 & 0.18 & 0.025 & -0.78 & -0.05 & 0.16 & 0.14 & 0.225 & -0.10 & 0.43 \\
\hline Positive Affect (T2) & -2.88 & 0.95 & 0.002 & -4.74 & -1.03 & 2.06 & 0.69 & 0.003 & 0.70 & 3.42 \\
\hline Negative Affect (T2) & 4.02 & 0.90 & 0.000 & 2.26 & 5.78 & 1.92 & 0.66 & 0.004 & 0.63 & 3.21 \\
\hline $\begin{array}{l}\text { Adherence to Socially Restrictive } \\
\text { (CDC) Public Health Behaviors (T2) }\end{array}$ & 0.23 & 0.07 & 0.000 & 0.10 & 0.36 & -0.11 & 0.05 & 0.028 & -0.20 & -0.01 \\
\hline $\begin{array}{l}\text { Adherence to Non-Restrictive (CDC) } \\
\text { Public Health Behaviors (T2) }\end{array}$ & 0.36 & 0.08 & 0.000 & 0.21 & 0.51 & -0.10 & 0.06 & 0.068 & -0.21 & 0.01 \\
\hline $\begin{array}{l}\text { Support for Socially Restrictive Public } \\
\text { Health Behaviors to Reduce Spread of } \\
\text { COVID-19 (T2) }\end{array}$ & 0.95 & 0.13 & 0.000 & 0.70 & 1.21 & -0.43 & 0.09 & 0.000 & -0.62 & -0.25 \\
\hline $\begin{array}{l}\text { Social (National) Identity Affirming } \\
\text { Behaviors in Isolation (T2) }\end{array}$ & -0.02 & 0.13 & 0.887 & -0.27 & 0.23 & 0.46 & 0.09 & 0.000 & 0.27 & 0.64 \\
\hline $\begin{array}{l}\text { Identity Non-Specific Social Behaviors } \\
\text { in Isolation (T2) }\end{array}$ & 0.00 & 0.12 & 0.978 & -0.24 & 0.23 & 0.15 & 0.09 & 0.085 & -0.02 & 0.33 \\
\hline
\end{tabular}

Note. $b$ values reflect non-standardized path estimates from one SEM model including all measured variables simultaneously. Realistic and Symbolic Threat were covaried in the model. All outcomes were covaried with each other in the model. We note that participants in Study 3 were the same as those recruited in Study 1 (which reflects responses at T1 in Study 3). Bolded values indicate statistical significance. 
Realistic and Symbolic Threats of COVID-19

\section{General Discussion}

We validated a ten-item scale assessing two kinds of psychological threats—realistic threat and symbolic threat - in response to the COVID-19 pandemic. Using cross-sectional and longitudinal methodologies, we found the psychometric properties of the scale were sound, with exploratory factor analysis (Study 1) and confirmatory factor analysis (Study 2) supporting two distinct types of COVID-19 threat (realistic and symbolic). In Study 3, we found evidence of scalar invariance when administering the scale twice over a one-week period (Flake, et al., 2017).

Our scale demonstrated convergent and divergent validity. Realistic and symbolic threats were significantly related to individual difference traits linked to threat sensitivity. Yet, COVID19 threats were not reliably related to individual difference traits less clearly tied to threat sensitivity. This pattern of results was robust when we assessed COVID-19 threat and the individual difference traits at the same time, as well as when we assessed the individual difference traits five months prior to the pandemic hitting the United States.

Both threats uniquely predicted important outcomes for psychological health and public health, when measured simultaneously with (Study 1 and 2) or one week prior (Study 3) to outcome assessment. Realistic and symbolic threat uniquely predicted greater negative affect, and more intrusive thoughts about the pandemic. Realistic threat most reliably predicted increased anxiety and diminished life-satisfaction, while symbolic threat most consistently predicted having an avoidant response to the pandemic.

Realistic and symbolic threats also had significant yet different consequences for support and self-reported adherence to restrictive public health behaviors essential to stopping the spread of the virus. Americans who perceived high levels of realistic threat were more likely to support 
Realistic and Symbolic Threats of COVID-19

and self-reportedly adhere to social distancing even though social distancing might disrupt the norms and structures they might associate with American identity. In direct contrast, symbolic threat of COVID-19 to American national identity predicted less support for social distancing. Importantly however, if people did engage in social distancing, experiencing symbolic threat predicted engaging in creative behaviors to express and maintain a sense of American identity even in isolation.

\section{Implications}

The Integrated COVID-19 Threat Scale provides a solid starting point for measuring the psychological threats tied to COVID-19 and the public health measures that are reshaping our society. Although the realistic threat of disease is obvious, we leverage insights from theories of intergroup relations, to argue the importance of another form of threat-symbolic threats to social identity — especially as they relate to socially restrictive public health behaviors. Future interventions to COVID-19 — and other pandemics — should work to minimize both realistic and symbolic threats. Our work is also one of the first papers to demonstrate the validity of applying theories of intergroup threat (Stephan et al., 2009) to understand how people perceive threats from an agent or entity other than another social group (also see Gamez-Djokic \& Waytz, in press).

\section{Limitations and Future Directions}

We note limitations of this work. First, we only assessed COVID-19 threat amongst Americans. People from different nations might be impacted differently by COVID-19, and may have different responses to symbolic or realistic threats of the virus. For instance, nations with more (or less) vulnerable health care systems, or with greater (or less) poverty may be most susceptible to realistic threats posed by the pandemic. 
Realistic and Symbolic Threats of COVID-19

Another limitation is that we only considered threats to national groups. While clearly relevant within national contexts (Maxouris, et al., 2020; Sanchez, 2020), the virus may also have distinct implications for group contexts based on ethnicity (Ro, 2020), religion (Chebbine, 2020), or social class (Blow, 2020). Future work examining COVID-19 threat in other group contexts is essential. It will also be important for future research to assess the realistic and symbolic threats of COVID-19 to people's global identity (McFarland, \& Brown, 2012) as the virus impacts the whole world.

Our assessment of symbolic threat was limited to the group level. Future work is needed to test how the COVID-19 pandemic might elicit individual symbolic threats such as dishonor (Stephan \& Renfro, 2002). For example, individuals may feel dishonor if they feel they are not adequately contributing to collective efforts in response to the pandemic. Finally, this research relied on self-reported measures: More research is also essential to replicate our findings when assessing actual behavior.

We acknowledge some unexpected results. Symbolic threat was associated with greater positive affect, although exploratory mediation analysis suggests this might be due to symbolic threat increasing social identity affirming behaviors. Values relating to self-enhancement were associated with COVID-19 threat. We did not predict this a priori, but previous work has shown self-enhancement to be associated with threat sensitivity (Schwartz et al., 2000). Finally, while symbolic threat was more robustly associated with impact avoidance than realistic threat as we expected, Study 2 suggested that realistic threat is also associated with impact avoidance. We refrain from speculating on this inconsistency, as further research is needed to replicate this effect. 
Realistic and Symbolic Threats of COVID-19

\section{Conclusion}

As the scientific community rallies to contain COVID-19 and mitigate its psychological toll, it is essential to fully capture how people feel threatened by the pandemic. We offer a brief scale which captures two kinds of threat, and present preliminary evidence that it may be important for public health initiatives to not only help protect people's physical bodies, but also their social identities. 
Realistic and Symbolic Threats of COVID-19

\section{References}

Altemeyer, B. (1988). Enemies of freedom: Understanding right-wing authoritarianism. JosseyBass: San Francisco, CA.

Beck, A. T., Epstein, N., Brown, G., \& Steer, R. A. (1988). An inventory for measuring clinical anxiety: Psychometric properties. Journal of Consulting and Clinical Psychology, 56(6), 893-897. doi:10.1037/0022-006X.56.6.893

Blow, C.M. (2020, April 5). Social distancing is a privilege: The idea that this virus is an equalopportunity killer must itself be killed. The New York Times. https://www.nytimes.com/2020/04/05/opinion/coronavirus-social-distancing.html

Byrne, B. M. (1994). Structural Equation Modeling with EQS and EQS/WINDOWS: Basic Concepts, Applications, and Programming. SAGE.

Byrne, B. M., Shavelson, R. J., \& Muthén, B. (1989). Testing for the equivalence of factor covariance and mean structures: the issue of partial measurement invariance. Psychological bulletin, 105(3), 456-466. doi: 10.1037/0033-2909.105.3.456.

Carpenter, S. (2018). Ten steps in scale development and reporting: A guide for researchers. Communication Methods and Measures, 12(1), 25-44. doi:10.1080/19312458.2017.1396583.

Chebbine, L. (2020, April 7). Coronavirus impacts religion around the world: COVID-19 is altering religious practices across the globe amid service cancellations and closures of places of worship. U.S. News. https://www.usnews.com/news/photos/2020/04/07/photoshow-coronavirus-is-impacting-religion-around-the-world

Chen, F. F. (2007). Sensitivity of goodness of fit indexes to lack of measurement invariance. Structural Equation Modeling: A Multidisciplinary Journal, 14(3), 464-504. 
Realistic and Symbolic Threats of COVID-19

Davies, R., Partington, R., \& Wearden, G. (2020, February 27). Coronavirus fears trigger biggest one-day fall on US stock market. The Guardian.

https://www.theguardian.com/business/2020/feb/27/coronavirus-could-trigger-damageon-scale-of-2008-financial-crisis-covid-19

de la Sablonnière, R., Auger, E., Taylor, D. M., Crush, J., \& McDonald, D. (2013). Social change in South Africa: A historical approach to relative deprivation. British Journal of Social Psychology, 52(4), 703-725. doi: 10.1111/bjso.12003

Diener, E., Emmons, R. A., Larsen, R. J., \& Griffin, S. (1985). The satisfaction with life scale. Journal of Personality Assessment, 49(1), 71-75. doi:10.1207/s15327752jpa4901_13

Duckitt, J., \& Fisher, K. (2003). The impact of social threat on worldview and ideological attitudes. Political Psychology, 24(1), 199-222. doi: 10.1111/0162-895X.00322

Esses, V. M., Jackson, L. M., \& Armstrong, T. L. (1998). Intergroup competition and attitudes toward immigrants and immigration: An instrumental model of group conflict. Journal of Social Issues, 54(4), 699-724. doi:10.1111/j.1540-4560.1998.tb01244.x

Everett, J. A. C., Colombatto, C., Chituc, V., Brady, W. J., \& Crockett, M. (2020). The effectiveness of moral messages on public health behavioral intentions during the COVID-19 pandemic [Preprint]. PsyArXiv. doi: 10.31234/osf.io/9yqs8

Flake, J., Pek, J., \& Hehman, E. (2017). Construct validation in social and personality research: Current practice and recommendations. Social Psychological and Personality Science, 8(4), 370-378. doi: 10.1177/1948550617693063

Gamez-Djokic, M. \& Waytz, A. (in press) Concerns about automation and negative sentiment towards immigration. Psychological Science. 
Realistic and Symbolic Threats of COVID-19

Gelfand, M. J., Raver, J. L., Nishii, L., Leslie, L. M., Lun, J., Lim, B. C., Duan, L., Almaliach, A., Ang, S., Arnadottir, J., Aycan, Z., Boehnke, K., Boski, P., Cabecinhas, R., Chan, D., Chhokar, J., D’Amato, A., Ferrer, M., Fischlmayr, I. C., ... Yamaguchi, S. (2011). Differences between tight and loose cultures: A 33-Nation Study. Science, 332(6033), 1100. doi: $10.1126 /$ science. 1197754

Gosling, S. D., Rentfrow, P. J., \& Swann, W. B. (2003). A very brief measure of the Big-Five personality domains. Journal of Research in Personality, 37(6), 504-528. doi: $10.1016 / \mathrm{S} 0092-6566(03) 00046-1$

Hawryluck, L., Gold, W. L., Robinson, S., Pogorski, S., Galea, S., \& Styra, R. (2004). SARS control and psychological effects of quarantine, Toronto, Canada. Emerging Infectious Diseases, 10(7), 1206-1212. doi: 10.3201/eid1007.030703

Hennekens, C. H., George, S., Adirim, T. A., Johnson, H., \& Maki, D. G. (2020, March 17). The Emerging Pandemic of Coronavirus: The Urgent Need for Public Health Leadership [Journal Pre-proof]. https://www.amjmed.com/action/showPdf?pii=S0002$9343 \% 2820 \% 2930207-2$

Horowitz, M., Wilner, N., \& Alvarez, W. (1979). Impact of event scale: A measure of subjective stress: Psychosomatic Medicine, 41(3), 209-218. doi:10.1097/00006842-19790500000004

Hu, L., \& Bentler, P. M. (1999). Cutoff criteria for fit indexes in covariance structure analysis: Conventional criteria versus new alternatives. Structural Equation Modeling: $A$ Multidisciplinary Journal, 6(1), 1-55. doi:10.1080/10705519909540118 
Realistic and Symbolic Threats of COVID-19

Jetten, J., Branscombe, N. R., Haslam, S. A., Haslam, C., Cruwys, T., Jones, J. M., Zhang, A. (2015). Having a lot of a good thing: Multiple important group memberships as a source of self-esteem. PLoS One, 10, 1-29. doi: 10.1371/journal.pone.0124609.

Kachanoff, F.J., Kteily, N., Khullar, T., Park, H.J., \& Taylor, D.M., (in press). Determining our destiny: Do restrictions to collective autonomy fuel collective action. Journal of Personality and Social Psychology. doi: 10.1037/pspi0000217

Kachanoff, F. J., Taylor, D. M., Caouette, J., Khullar, T. H., \& Wohl, M. J. A. (2019). The chains on all my people are the chains on me: Restrictions to collective autonomy undermine the personal autonomy and psychological well-being of group members. Journal of Personality and Social Psychology, 116(1), 141-165.

doi:10.1037/pspp0000177

Major, B., Mendes, W. B., \& Dovidio, J. F. (2013). Intergroup relations and health disparities: A social psychological perspective. Health Psychology, 32(5), 514-524. doi: $10.1037 / \mathrm{a} 0030358$

Matsuishi, K., Kawazoe, A., Imai, H., Ito, A., Mouri, K., Kitamura, N., Miyake, K., Mino, K., Isobe, M., Takamiya, S., Hitokoto, H., \& Mita, T. (2012). Psychological impact of the pandemic (H1N1) 2009 on general hospital workers in Kobe. Psychiatry and Clinical Neurosciences, 66(4), 353-360. doi:10.1111/j.1440-1819.2012.02336.x

Maxouris, C., Almasy, S., \& McLaughlin, E. (2020, March 12). US coronavirus: For many Americans, a normal life is on hold-CNN. https:/www.cnn.com/2020/03/12/health/coronavirus-us-updates-casesthursday/index.html 
Realistic and Symbolic Threats of COVID-19

McFarland, S., Webb, M., \& Brown, D. (2012). All humanity is my ingroup: A measure and studies of identification with all humanity. Journal of personality and social psychology, 103(5), 830-853.

Meredith, W. (1993). Measurement invariance, factor analysis and factorial invariance. Psychometrika, 58(4), 525-543. doi:10.1007/BF02294825

O’Leary, A., Jalloh, M. F., \& Neria, Y. (2018). Fear and culture: Contextualising mental health impact of the 2014-2016 Ebola epidemic in West Africa. BMJ Global Health. Retrieved March 31, 2020, from https://gh.bmj.com/content/3/3/e000924.abstract

Oyserman, D. (2007). Social identity and self-regulation. In A. Kruglanski, \& T. Higgins (Eds.), Social Psychology: Handbook of basic principles (pp. 432-453). New York, NY: Guilford Press.

Patterson, N. (2020, March 26). Layoffs, Job Losses-COVID-19 Impact Expected to Play Out Over Months. WBHM 90.3. https://wbhm.org/2020/layoffs-job-losses-covid-19-impactexpected-play-months/

Pew Research Center (Wave 63.5, March 10, 2020). U.S. public sees multiple threats from the Coronavirus - and concerns are growing. https://www.people-press.org/2020/03/18/u-spublic-sees-multiple-threats-from-the-coronavirus-and-concerns-are-growing/

Ro, C. (2020, April). Coronavirus: Why some racial groups are more vulnerable. BBC. https://www.bbc.com/future/article/20200420-coronavirus-why-some-racial-groups-aremore-vulnerable

Rubin, M. (2018). Fear of self-annihilation and existential uncertainty as predictors of worldview defense: Comparing terror management and uncertainty theories. The Journal of Social Psychology, 158(3), 298-308. doi:10.1080/00224545.2017.1341375 
Realistic and Symbolic Threats of COVID-19

Sanchez, R. (2020, March 15). This past week signaled a turning point in America's health emergency. CNN. https:/www.cnn.com/2020/03/15/us/coronavirus-pandemicus/index.html

Schneider, T. R. (2004). The role of neuroticism on psychological and physiological stress responses. Journal of Experimental Social Psychology, 40(6), 795-804. doi:10.1016/j.jesp.2004.04.005

Schwartz, S. H., Sagiv, L., \& Boehnke, K. (2000). Worries and Values. Journal of Personality, 68(2), 309-346. doi:10.1111/1467-6494.00099

Smith, R. D., Keogh-Brown, M. R., Barnett, T., \& Tait, J. (2009). The economy-wide impact of pandemic influenza on the UK: A computable general equilibrium modelling experiment. $B M J$, 339. doi:10.1136/bmj.b4571

Steiger, J. H. (1990). Structural Model Evaluation and Modification: An Interval Estimation Approach. Multivariate Behavioral Research, 25(2), 173-180. doi:10.1207/s15327906mbr2502_4

Stephan, W. G., \& Renfro, C. L. (2002). The role of threats in intergroup relations. In D. Mackie \& E. R. Smith (Eds.), From prejudice to intergroup emotions (pp. 191-208). New York: Psychology Press.

Stephan, W. G., \& Stephan, C. W. (2000). An integrated threat theory of prejudice. In S. Oskamp (Ed.), Reducing Prejudice and Discrimination (pp. 23-45). Mahwah, NJ: Lawrence Erlbaum Associates.

Stephan, W. G., Ybarra, O., Morrison, K. R. (2009). Intergroup threat theory. In: T. Nelson ( Ed.), Handbook of Prejudice (pp. 43-59). Mahwah, NJ: Lawrence Erlbaum. 
Realistic and Symbolic Threats of COVID-19

Stern, P. C., Dietz, T., \& Guagnano, G. A. (1998). A brief inventory of values. Educational and psychological measurement, 58(6), 984-1001. doi: $\underline{10.1177 / 0013164498058006008}$

Tajfel, H., \& Turner, J. C. (1979). An integrative theory of intergroup conflict. In W. G. Worchel, \& S. Austin (Eds.), The social psychology of intergroup relations (pp. 33-47). Monterey, CA: Brooks/Cole.

Usborne, E., \& Taylor, D. M. (2010). The role of cultural identity clarity for self-concept clarity, self-esteem, and subjective well-being. Personality and Social Psychology Bulletin, 36, 883-897. DOI: 10.1177/0146167210372215

ur-Rehman, Z., Abi-Habib, M., Mehsud, I. T., \& Bashir, S. (2020, March 26). 'God Will Protect Us': Coronavirus Spreads Through an Already Struggling Pakistan. The New York Times. https://www.nytimes.com/2020/03/26/world/asia/pakistan-coronavirus-tablighijamaat.html

Van Bavel, J. J., Baicker, K., Boggio, P., Capraro, V., Cichocka, A., Crockett, M., ... Willer, R. (2020). Using social and behavioural science to support COVID-19 pandemic response. Nature Human Behavior.

Viboud, C., Tam, T., Fleming, D., Handel, A., Miller, M. A., \& Simonsen, L. (2006). Transmissibility and mortality impact of epidemic and pandemic influenza, with emphasis on the unusually deadly 1951 epidemic. Vaccine, 24(44), 6701-6707. https://doi.org/10.1016/j.vaccine.2006.05.067

Watson, D., Clark, L. A., \& Tellegen, A. (1988). Development and validation of brief measures of positive and negative affect: The PANAS scales. Journal of Personality and Social Psychology, 54(6), 1063-1070. https://doi.org/10.1037/0022-3514.54.6.1063 
Realistic and Symbolic Threats of COVID-19

Webster, D. M., \& Kruglanski, A. W. (1994). Individual differences in need for cognitive closure. Journal of personality and social psychology, 67(6), 1049-1062. doi: $10.1037 / 0022-3514.67 .6 .1049$

Zárate, M. A., Garcia, B., Garza, A. A., \& Hitlan, R. T. (2004). Cultural threat and perceived realistic group conflict as dual predictors of prejudice. Journal of experimental social psychology, 40(1), 99-105. doi: 10.1016/S0022-1031(03)00067-2 


\section{$\underline{\text { Supplemental Materials }}$}

Measuring Realistic and Symbolic Threats of COVID-19 and their Unique Impact on Wellbeing and Adherence to Public Health Behaviors

\section{Study 1}

Detailed Description of Sample and Statistical Power..................................... 3

Detailed Description of Measures......................................................

Detailed Description of Exploratory Factor Analysis...................................

Detailed Results Testing Main Hypotheses.......................................... 10

Scales as Shown in Qualtrics Survey .............................................. 14

\section{Study 2}

Detailed Description of Sample and Statistical Power...................................24

Detailed Description of Measures................................................24

Detailed Description of Confirmatory Factor Analysis...................................27

Detailed Results Testing Main Hypotheses...........................................27

Scales as Shown in Qualtrics Survey ................................................ 31

\section{Study 3}

Detailed Description of Sample and Statistical Power................................... 38

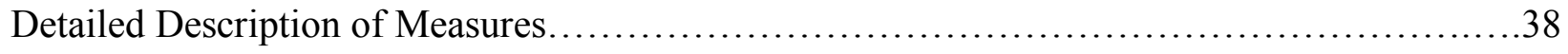

Detailed Description of Invariance Analysis........................................ 39

Detailed Results Testing Main Hypotheses...........................................41

Scales as Shown in Qualtrics Survey.............................................4

\section{Supplemental Analyses with Political Ideology}

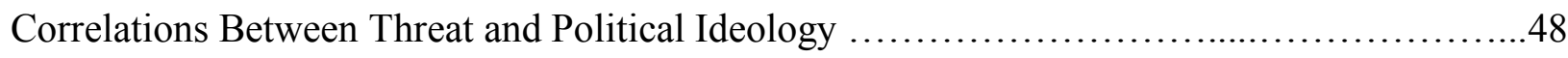


Study 1 SEM Model Including Political Ideology as Predictor..............................49

Study 2 SEM Model Including Political Ideology as Predictor .............................50

Study 1 SEM Model Including Political Ideology as Predictor ............................52

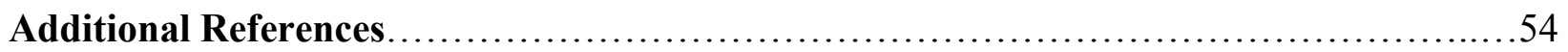

Data and analysis scripts are available online on the OSF:

https://osf.io/p39ru/?view only=55abd11ea00744abae5924a02de795c4 


\section{Study 1 - Detailed Description of Sample, Measures and Results}

Sample. Between March $19^{\text {th }}$ and $20^{\text {th }}, 2020,399$ American participants were recruited from MTurk. After pre-registered exclusions, 346 participants (160 male, 184 female, 2 other; $M_{\text {age }}=41.51, S D_{\text {age }}=13.46 ; 80.9 \%$ White, $9.5 \%$ Black or African American, $4.9 \%$ Latinx/Hispanic) completed all measures during the COVID-19 crisis. One-hundred and ninetythree of these participants (after exclusions, 86 male, 105 female, 2 other, $M_{\text {age }}=42.27$, $S D_{a g e}=13.99 ; 85.5 \%$ White, $8.8 \%$ Black or African American, 3.1\% Latinx/Hispanic) also had completed all non-COVID-19 items in October 2019. We determined our sample size on the basis of the number of participants we had available in our pre-COVID-19 sample, and thus we aimed for $\sim 200$ participants who completed pre-COVID measures and $\sim 200$ new participants (to increase sample size and statistical power). A large sample size of $\sim 400$ (or $\sim 200$ cases for our longitudinal sub-sample) provides sufficient power $(>80 \%)$ for the correlational based analyses we used in this study in which we expected effects of at least $r=.20$. We also had at least 5-10 observations per parameter for our planned SEM analysis (in this case at least an $n=150$; see Kline, 2011). See our pre-registration at https://aspredicted.org/blind.php? $\mathrm{x}=\mathrm{zj} 99 \mathrm{wh}$ for more information $^{1}$

\section{Measures}

All scores represent the means of all items, with the exception of the Beck Anxiety Inventory and Impact of the COVID-19 event scale (i.e., subjective stress) which was summed according to guidelines (Gosling, Rentfrow, \& Swann, 2003; Horowitz, Wilner, \& Alverez, 1979).

\footnotetext{
${ }^{1}$ We note that the scales focused on in Study 1 were part of a larger study focusing on the impact of COVID-19 threat and morality most broadly. See registration for all collected measures.
} 
Integrative COVID-19 Threat Scale. All items were framed with the opening: "How much of a threat, if any, is the coronavirus outbreak to..." and were rated from 1 (Not a threat) to 4 (Major Threat). To assess realistic threat, we adapted 5 pre-existing items $\left(\alpha_{\text {during_cov19 }}=.77\right)$ used by the Pew Research Poll (Pew Research Poll, Wave 63.5, March 10, 2020) to document perceived threat of COVID-19. Participants were asked about the threat of COVID-19 to "your personal health", "the health of the U.S. population as a whole", "your personal financial safety", "the U.S economy", and "day-to-day life in your local community"

We used 5 items $\left(\alpha_{\text {during_Cov19 }}=.85\right)$ to assess symbolic threat of COVID-19. Four items were based on Stephan and colleagues' (2006) definition of symbolic threat cited above. We asked participants if they felt COVID-19 poses a threat to "What it means to be American", "American values and traditions", "The maintenance of law and order in America", and "American Democracy". We also included one item assessing threat to the "The rights and freedoms of the U.S. population as a whole" adapted from Kachanoff and colleagues (2019)².

Convergent validity. We tested whether each dimension of COVID-19 (as well as the total threat scale) related significantly to several individual difference traits which were found in previous research to associate with threat sensitivity in other contexts (e.g., intergroup contexts). These included:

The Need for Cognitive Closure. We assessed need for cognitive closure with 15 items (Webster \& Kruglanski, 1998). Participants rated agreement on a scale anchored at 1 (Completely Disagree) and 6 (Completely Agree). A sample item included: "I feel

\footnotetext{
${ }^{2}$ We generated a pool of 20 items to explore different types of threat which go beyond the focus of this paper (e.g., threat to loved ones). All items are available in Supplemental Materials and OSF data. We do not focus on items pertaining to loved ones because of their substantial overlap with items pertaining to the self. We also limited the realistic threat items to only those used in the PEW poll so our findings can generalize to their report. We validated our scale structure in two subsequent pre-registered studies (Study 2 and 3) using only the 10-item scale.
} 
uncomfortable when I don't understand the reason why an event occurred in my life" $\left(\alpha_{\text {before_Cov19 }}=.90 ; \alpha_{\text {during_Cov19 }}=.89\right)$.

The Belief in a Dangerous World. We assessed belief in a dangerous world with 12 items (Altemeyer, 1988). Participants rated agreement on a scale anchored a 1 (Strongly Disagree) and 7 (Strongly Agree). A sample item included: "There are many dangerous people in our society who will attack someone out of pure meanness, for no reason at all" $\left(\alpha_{\text {before_cov19 }}=\right.$ $\left..92 ; \alpha_{\text {during_Cov19 }}=.93\right)$.

Values associated with Conservation. We assessed the importance that people placed on three values tapping into Schwartz's (1992) conceptualization of conservation: valuing security, conformity, and tradition (items adapted from Stern, Dietz, \& Guagnano, 1998). Participants rated each value (e.g., security) on a scale anchored at 0 (Opposed to My Principals) and 8 (Of Supreme Importance; $\left.\alpha_{\text {before_COV19 }}=.63 ; \alpha_{\text {during_Cov19 }}=.65\right)$

Emotional (In)stability. We assessed emotional stability using two items from the Ten Item Personality Inventory (Gosling, Rentfrow, \& Swann, 2003). Participants rated if they saw themselves as having different traits on a scale anchored at 1 (Strongly Disagree) to 7 (Strongly Agree). A sample item included: "Anxious, easily upset" ( $\left.r_{\text {before_Cov19 }}=.69 ; r_{\text {during_Cov19 }}=.41\right)$.

Divergent Validity. We also examined if, compared to values associated with conservation, there would be relatively weaker associations between COVID-19 threat and other values assessed using the Schwartz value survey: These included values associated with openness to change (i.e., stimulation, self-direction; $r_{\text {before_Cov19 }}=.28 ; r_{\text {during_Cov19 }}=.23$ ), values associated with self-enhancement (i.e., achievements, hedonism, power; $\alpha_{\text {before_Cov19 }}=.44$; $\alpha_{\text {during_Cov19 }}=.58$ ), and values associated with self-transcendence (i.e., universalism, benevolence; $\left.r_{\text {before_COV19 }}=.13 ; r_{\text {during_COV19 }}=.33\right)$. 
Similarly, we examined whether compared to emotional stability we would find relatively weaker associations between COVID-19 threat and other personality traits assessed using the Ten Item Personality Inventory: extraversion $\left(r_{\text {before_Cov19 }}=.70 ; r_{\text {during_Cov19 }}=.69\right)$, agreeableness $\left(r_{\text {before_Cov19 }}=.18 ; r_{\text {during_Cov19 }}=.31\right)$, conscientiousness $\left(r_{\text {before_cov19 }}=.51\right.$; $\left.r_{\text {during_Cov19 }}=.49\right)$, and openness to experience $\left(r_{\text {before_COV19 } 19}=.52 ; r_{\text {during_Cov19 }}=.46\right)$.

Because there is no clear theoretical basis to suggest their association with threat, we did not expect associations with perceived threat from COVID-19.

\section{Criterion Validity.}

We assessed psychological distress in terms of people's general anxiety and subjective distress response to the COVID-19 pandemic specifically.

General Anxiety. We assessed general anxiety using the 9-item Beck Anxiety Inventory (Beck, Epstein, Brown, \& Steer, 1988). Participants rated symptom severity of anxiety symptoms in the past week on a scale anchored at 0 (Not at all) to 3 (Severely - I could barely stand it; $\left.\alpha_{\text {before_COV19 }}=.85 ; \alpha_{\text {during_Cov19 }}=.87\right)$.

\section{Subjective distress caused by the COVID-19 pandemic assessed with the Impact of}

Event Scale. We assessed subjective distress in response to the pandemic by adapting the 15item Impact of Event Scale (Horowitz, Wilner, \& Alverez, 1979). The scale assesses potentially maladaptive responses to traumatic or stressful events. The scale includes two distinct sub-scales assessing (1) impact intrusion (i.e., whether people have intrusive thoughts about the event, e.g., "I thought about the event when I didn't mean to" $\alpha_{\text {during_Cov19 }}=.87$ ); and (2) impact avoidance (i.e., whether people avoided thinking about the event, e.g., "I stayed away from reminders of the virus"; $\left.\alpha_{\text {during_Cov19 }}=.81\right)$. Participants rated how much each of these affective responses to 
COVID-19 were true of how they felt during the past seven days. Responses were rated on a scale anchored at 0 (Not at all) and 3 (Often).

\section{Results}

\section{Factor Structure of COVID Threat Scale}

We explored the factor structure of the ten-item threat scale using the best practices for Exploratory Factor Analysis outlined by Carpenter (2018). We first verified the factorability of the data. Bartlett's test of sphericity was significant $\left(\chi^{2}(45)=1241.67, \mathrm{p}<.001\right)$ indicating that the items as a whole were significantly correlated. The Kaiser-Meyer-Olkin Measure of sampling adequacy was larger than $.60(\mathrm{KMO}=.863)$ which also indicated that it was appropriate to proceed with Factor Analysis on the present set of items (McCrosky \& Young, 1979; Pett, Lackey, \& Sullivan, 2003; Tabachnick \& Fidell, 2007). Seven of the ten items had communalities greater than (.40) which is considered common in the social sciences (Costello and Osborne, 2005). Three items had lower communalities of .28 ("How much of a threat, if any, is the coronavirus outbreak for the U.S. economy"), .31 ("How much of a threat, if any, is the coronavirus outbreak for day-to-day life in your local community) and .33 ("how much of a threat, if any, is the coronavirus outbreak for your personal financial safety"). Taken together, these preliminary findings suggested that it would be justifiable to conduct factor analysis on these ten items, however, three low communalities indicated that the item set might contain multiple factors.

Because we had a theoretical basis to expect a specific factor structure of our scale we avoided using Principal Component Analysis which can inflate the number of factors retained (e.g., Costello \& Osborne, 2005; Preacher \& MacCallum, 2003) and instead used a common factor analysis approach which is optimal when the intent is to later submit the hypothesized 
model to confirmatory factor analysis (e.g., Worthington \& Whittaker, 2006). We observed nonnormality in the distributions of our scale items, and thus, we opted to use Principal Axis Factoring $(\mathrm{PAF})$ which is considered the most robust method for non-normally distributed data (Fabrigar et al., 1999).

To determine the number of factors to retain we assessed the scree plot of the Eigenvalues derived from our factors (Preacher \& MacCallum, 2003). As illustrated in supplemental Figure 1, the elbow of the Scree plot indicated a two-factor structure best represented the data. In addition, we conducted a parallel analysis (Horn,1965; Kline, 2013) in which we compared the eigenvalues derived from our data to eigenvalues derived from a MonteCarlo simulation (Watkins, 2006; 1000 samples, assuming a sample size of $\mathrm{N}=346$, and ten items). The eigenvalue of our first Factor (Eigenvalue $=4.20$ ) and our second Factor (Eigenvalue $=1.64$ ) were both larger than the eigenvalues of the two largest factors derived from the simulation data (Simulation Factor $1=1.27$; Simulation Factor $2=1.19$ ). These results also indicated that a 2 -factor structure best fit our data.

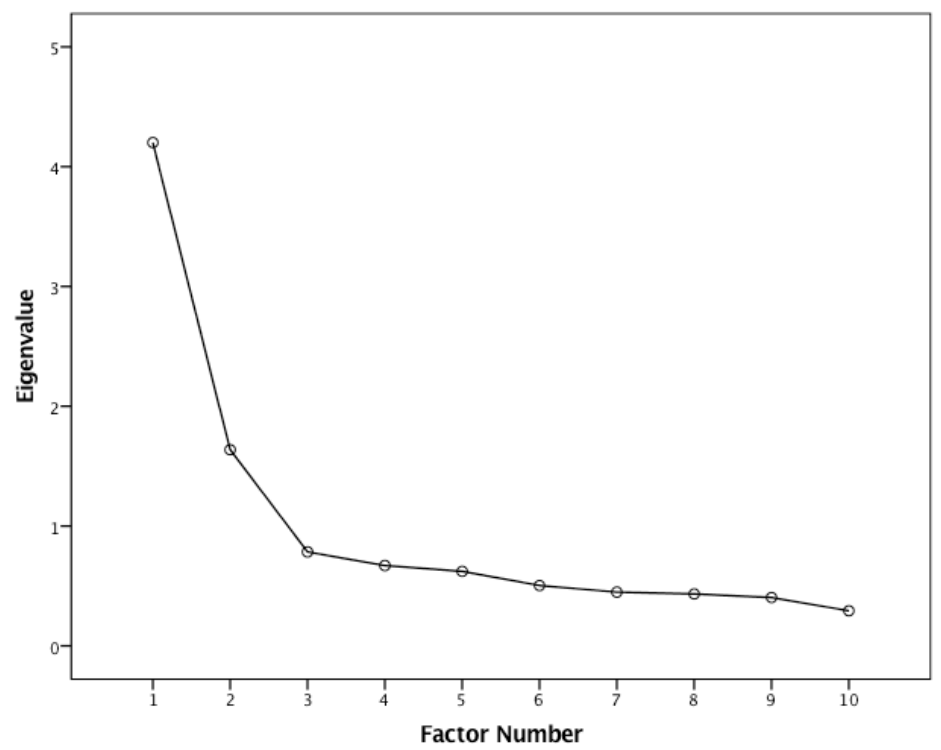


Supplement Figure 1. Scree Plot of Factor Analysis Conducted on 10-item COVID-19 Threat scale (Study 1).

To identify our factors, we used an Oblique rotation which is recommended when factors are expected to correlate. Given that symbolic and realistic threats to COVID-19 both in theory reflect the latent construct of psychological threat to the virus we expected both factors to correlate. We also avoided an orthogonal rotation approach (such as the Varimax rotation) because it can polarize the factor loadings by artificially preventing them from correlating (Tabachnick \& Fidell, 2001) and exacerbate the cross-loadings between factors (Fabrigar et al., 1999; Gorsuch, 1997). We used the Promax rotation because it is considered to be robust and is recommended by some over alternatives like the Direct Oblimin rotation (Thompson, 2004). As indicated in Table 2 of the main text, the ten items clearly loaded on to two distinct Factors reflecting our a priori expected theoretical constructs of Symbolic Threat (Factor 1) and Realistic Threat (Factor 2). All factor loadings of items (see Table 2 in Main Text) onto their respective factors were at least .511 or greater, and thus exceeded different cut off thresholds suggested in previous research (e.g., .32 by Worthington \& Whittaker, 2006; .35 by Clark \& Watson, 1995; .40 by Reinard, 2006; and .50 by Mertler \& Vannatta, 2001). We also did not observe any high cross-loadings on the non-target factors (loadings greater than .32 using the more conservative metric recommended by Worthington \& Whittaker, 2006). We also note that the 3 items which had relatively low communalities (threats to: personal financial safety, the U.S economy, and day-to-day life all had acceptable factor loadings ranging from .51 to .80 , and no problematic cross-loadings). In Supplemental Figure 2 we display the positioning of all items in 2dimensional space representing the two distinct factors.

(See Table 2 reported in Main Text) 


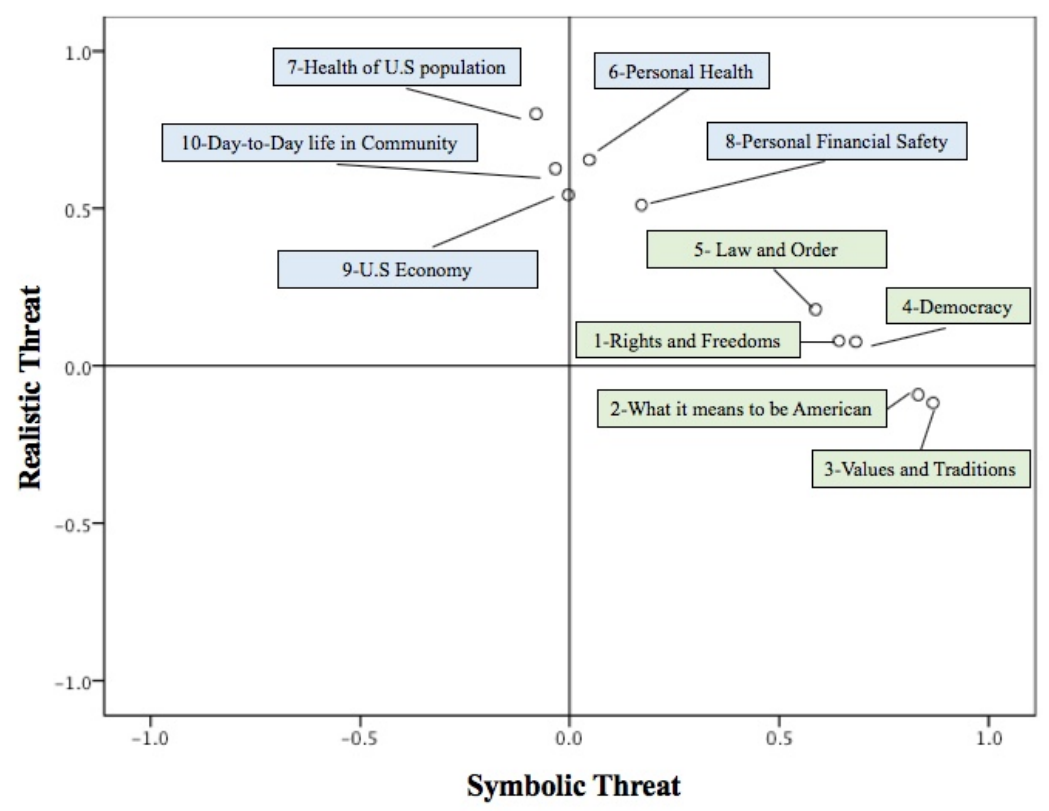

Supplemental Figure 2. Visual plot of all 10 COVID-19 threat scale items in two-dimensional space based on factor loadings derived from Principal Axis Factoring and Oblique Promax Rotation. Blue-labeled items reflect Realistic Threat items. Green-labeled items reflect Symbolic Threat items.

\section{Cross-Sectional Analysis (Full Sample)}

We report in Table 3 descriptive statistics for all scales measured during the COVID-19 crisis (i.e., $\mathrm{N}=346$ participants), as well as, the zero-order correlations between realistic and symbolic threat and each other variable.

(See Table 3 reported in Main Text)

Convergent and divergent validity. Overall, we found evidence for convergent (H1) and divergent (H2) validity of the COVID-19 threat scale. Consistent with the literature, the perceived threat of COVID-19 (combining both dimensions) was positively associated with the need for cognitive closure, belief in a dangerous world, values associated with conservation, and was negatively associated with emotional stability. In contrast, indicating divergent validity, 
threat to COVID-19 (combining both dimensions) was not significantly associated with any of the other dimensions of Schwartz's value scale or the Ten-Item-Personality Inventory.

Results were consistent when we examined the associations for each threat dimension separately, with a few exceptions. Valuing conservation was robustly associated with symbolic threat but not realistic threat. However, examination of the sub-values associated with conservation revealed that realistic threat was significantly related to valuing security $(r(346)=.15, p=.006)$, but not valuing tradition, or conformity. Symbolic threat in contrast was significantly associated with all three sub-dimensions (all $p s<.001)$. We also observed an unanticipated significant association between symbolic threat and values associated with selfenhancement.

Criterion Validity. We examined the association between realistic and symbolic threat, and the psychological distress that people may experience during the pandemic (i.e., anxiety, COVID-19 impact intrusion and COVID-19 impact avoidance) simultaneously within one structural equation path model (SEM; Byrne, 1994). This analysis was conducted using the Lavaan package in R (Rosseel, 2012). In the model, we regressed each of the three outcomes onto both threat dimensions. We allowed the two threat dimensions to covary, and, the three outcomes to covary. The model was fully saturated, $\chi^{2}(0)=0$.

Supporting hypothesis 3 , realistic threat was significantly positively associated with anxiety $(b=2.79,95 \% \mathrm{CI}[1.85,3,72], p<.001)$, as well as with COVID-19 impact intrusion $(b=3.18,95 \%$ CI $[2.29,4.07], p<.001)$, but was not associated with COVID-19 impact avoidance $(b=.25,95 \% \mathrm{CI}[-.72,1.22], p=.613)$. Symbolic threat was significantly positively associated with COVID-19 impact avoidance $(b=.98,95 \% \mathrm{CI}[.26,1.70], p=.008)$ and COVID-19 impact 
intrusion ( $b=1.10,95 \% \mathrm{CI}[.43,1.77], p=.001)$, but was not significantly associated with anxiety $(b=.56,95 \%$ CI $[-.14,1.26], p=.114)$.

Convergent and divergent validity. See Table 4 for descriptive statistics and correlations. Indicating convergent validity (H1), and consistent with our cross-sectional results, the perceived threat of COVID-19 (combining both dimensions) was positively associated with the need for cognitive closure, belief in a dangerous world, conservation, and negatively associated with emotional stability, when these individual differences were assessed 5 months before the global pandemic. Indicating divergent validity (H2), threat to COVID-19 (combining both dimensions) was not significantly associated with the other dimensions of Schwartz's value scale of the TenItem-Personality Invention assessed prior to the crisis, with the exception that total threat was significantly positively associated with values associated with self-enhancement.

Results were mostly consistent when we examined the associations for each threat dimension separately. Consistent with the cross-sectional data, values associated with conservation prior to the crisis were only associated with symbolic but not realistic threat when combined. Yet, when examining the sub-values relating to conservation, we found that realistic threat was significantly related to valuing security prior to the crisis $(r(192)=.19, p=.007)$ but not valuing tradition or conformity. Symbolic threat was significantly associated with valuing tradition $(r(192)=.19, p=.009)$ and security $(r(192)=.18, p=.015)$, and was marginally associated with conformity $(r(192)=.12, p=.097)$. We observed an unanticipated significant association between symbolic threat and values relating to self-enhancement. Also, realistic threat was associated with values relating to self-enhancement, and to self-transcendence. 
Criterion validity. Providing partial support for $\mathrm{H} 3$, realistic threat $(b=1,71,95 \%$ CI [.67, $2.75], p=.001)$ but not symbolic threat $(b=.28,95 \%$ CI $[-.50,1.06], p=.486)$ was associated with anxiety during the pandemic, controlling for base-line anxiety.

(See Table 4 reported in Main Text) 


\section{$\underline{\text { Study } 1 \text { (Qualtrics Survey) }}$}

Threat of COVID-19- Initial Item Pool: We initially generated an exploratory pool of 20 items to explore the threat of COVID-19. The final 10 items focused on in the paper are reported in Table 1 of the main text.

How much of a threat, if any, is the coronavirus outbreak for...

\begin{tabular}{|c|c|c|c|c|}
\hline & $\begin{array}{c}\text { Not a threat } \\
1\end{array}$ & $\begin{array}{c}\text { Minor threat } \\
2\end{array}$ & $\begin{array}{c}\text { Moderate threat } \\
3\end{array}$ & $\begin{array}{c}\text { Major threat } \\
4\end{array}$ \\
\hline Your personal health & $\bigcirc$ & 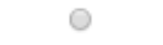 & $\odot$ & O \\
\hline The health of your loved ones & 0 & $\circ$ & $\bigcirc$ & 0 \\
\hline $\begin{array}{l}\text { The health of the U.S. population } \\
\text { as a whole }\end{array}$ & 0 & 0 & ○ & 0 \\
\hline Your personal financial safety & 0 & $\circ$ & 0 & 0 \\
\hline $\begin{array}{l}\text { The financial safety of your loved } \\
\text { ones }\end{array}$ & O & $\bigcirc$ & $\bigcirc$ & $\odot$ \\
\hline The U.S. economy & 0 & 0 & 0 & 0 \\
\hline $\begin{array}{l}\text { Your personal access to basic } \\
\text { resources like food and water }\end{array}$ & O & 0 & $\circ$ & $\circ$ \\
\hline $\begin{array}{l}\text { Your loved ones' access to basic } \\
\text { resources like food and water }\end{array}$ & O & 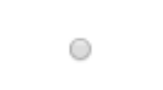 & $\circ$ & $\odot$ \\
\hline $\begin{array}{l}\text { The U.S. populations' access to } \\
\text { basic resources like food and } \\
\text { water as a whole }\end{array}$ & 0 & O & $\circ$ & 0 \\
\hline $\begin{array}{l}\text { Your personal access to health } \\
\text { care }\end{array}$ & 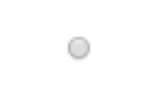 & 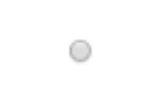 & 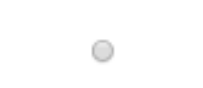 & 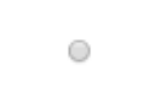 \\
\hline $\begin{array}{l}\text { Your loved ones' access to health } \\
\text { care }\end{array}$ & O & $\bigcirc$ & $\odot$ & 0 \\
\hline The U.S. healthcare system & $\bigcirc$ & $\bigcirc$ & $\bigcirc$ & $\bigcirc$ \\
\hline $\begin{array}{l}\text { Your personal rights and } \\
\text { freedoms }\end{array}$ & 0 & 0 & 0 & 0 \\
\hline $\begin{array}{l}\text { The rights and freedoms of your } \\
\text { loved ones }\end{array}$ & 0 & 0 & 0 & $\circ$ \\
\hline $\begin{array}{l}\text { The rights and freedoms of the } \\
\text { U.S. population as a whole }\end{array}$ & O & 0 & ○ & $\circ$ \\
\hline $\begin{array}{l}\text { Day-to-day life in your local } \\
\text { community }\end{array}$ & 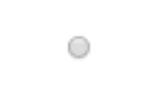 & 0 & $\circ$ & 0 \\
\hline What it means to be American & 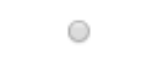 & $\circ$ & $\circ$ & ○ \\
\hline American values and traditions & $\bigcirc$ & $\bigcirc$ & $\bigcirc$ & $\bigcirc$ \\
\hline American democracy & 0 & 0 & 0 & 0 \\
\hline $\begin{array}{l}\text { The maintenance of law and } \\
\text { order in America }\end{array}$ & 0 & $\bigcirc$ & $\odot$ & 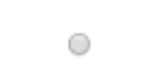 \\
\hline
\end{tabular}




\section{The Need for Cognitive Closure}

I don't like situations that are uncertain.

Completely disagree

1

$\circ \quad \mathrm{C}$

2

3

3

4

5

Completely agree

6

0

I dislike questions which could be answered in many different ways.

Completely disagree

1

$\bigcirc$
2

$\circ$
3

0
4

○
5

Completely agree

6

○

I find that a well ordered life with regular hours suits my temperament.

Completely disagree

1

$\bigcirc$
2

$\circ$
3

$\circ$

4

0
5

$\bigcirc$
Completely agree

6

○

I feel uncomfortable when I don't understand the reason why an event occurred in my life.

Completely disagree

1

$\bigcirc$
2

$\bigcirc$
3

$\bigcirc$
4

$\bigcirc$
5

0
Completely agree

6

○

I feel irritated when one person disagrees with what everyone else in a group believes.

Completely disagree

1

$\bigcirc$
2

0
3

$\bigcirc$
4

$\bigcirc$
5

$\bigcirc$
Completely agree

6

○ 
I don't like to go into a situation without knowing what I can expect from it.

Completely disagree

$$
1
$$

$\bigcirc$
2

$\bigcirc$
3

$\bigcirc$
4

○
Completely agree 6

$\mathrm{O}$

When I have made a decision, I feel relieved.

\section{Completely disagree}

1

$\bigcirc$
2

○
3

$\circ$
4

0
Completely agree

5

6

$\bigcirc$

When I am confronted with a problem, I'm dying to reach a solution very quickly.

Completely disagree

1

1
2

$\bigcirc$
3

0
4

○
Completely agree

6

○

I would quickly become impatient and irritated if I would not find a solution to a problem immediately.

\section{Completely disagree}

\section{1}

○
2

○
3

$\circ$
4

0
5

○
Completely agree

6

$\bigcirc$

I don't like to be with people who are capable of unexpected actions.

Completely disagree

1

$\bigcirc$
2

$\circ$
3

○
4

$\circ$
5

○

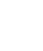


I dislike it when a person's statement could mean many different things.

Completely disagree

1

$\bigcirc$
2

0
O
Completely agree

6

O

I find that establishing a consistent routine enables me to enjoy life more.

Completely disagree

1

0
2

0
0 $\bigcirc$
Completely agree

6

0
6

I enjoy having a clear and structured mode of life.

Completely disagree

1

0
2

0
3

0
0

I do not usually consult many different opinions before forming my own view.

Completely disagree

$$
1
$$

$\bigcirc$
2

$\bigcirc$

\section{3}

$\bigcirc$
4

$\bigcirc$
5

0
Completely agree

6

○

I dislike unpredictable situations.

Completely disagree$$
1
$$

$\bigcirc$
2

$\bigcirc$

\section{3}

$\bigcirc$
4

$\bigcirc$
5

0
Completely agree

6

○ 


\section{The Belief in a Dangerous World}

Please indicate your agreement with the following statements.

It seems that every year there are fewer and fewer truly respectable people, and more and more persons with no morals at all who threaten everyone else.

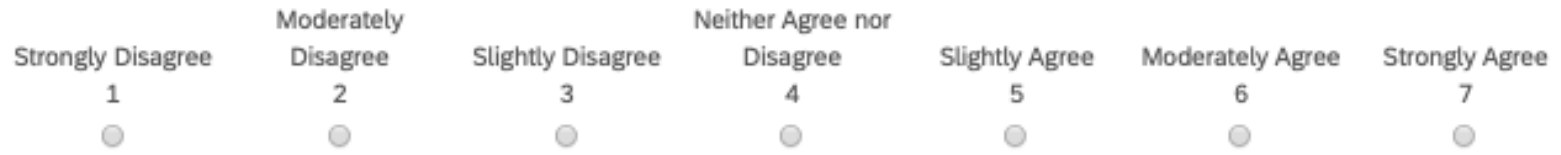

Although it may appear that things are constantly getting more dangerous and chaotic, it really isn't so. Every era has its problems, and a person's chances of living a safe, untroubled life are better today than ever before.

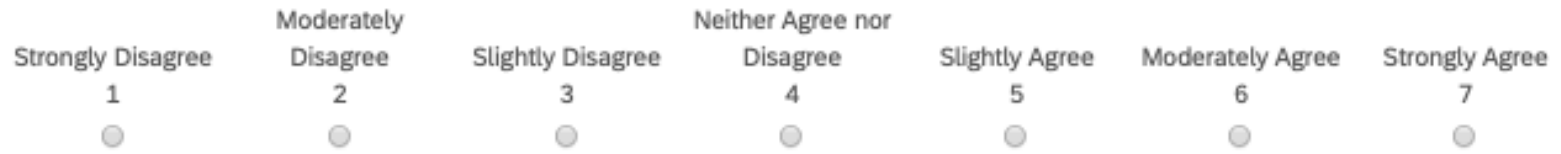

If our society keeps degenerating the way it has been lately, it's liable to collapse like a rotten log and everything will be chaos.

\begin{tabular}{ccccccc} 
& Moderately & \multicolumn{2}{c}{ Neither Agree nor } & Slightly Agree & Moderately Agree & Strongly Agree \\
Strongly Disagree & Disagree & Slightly Disagree & Disagree & 5 & 6 & 7 \\
1 & 2 & 3 & 4 & 0 & 0 & 0
\end{tabular}

Our society is not full of immoral and degenerate people who prey on decent people. News reports of such cases are grossly exaggerating and misleading.

\begin{tabular}{ccccccc} 
& Moderately & \multicolumn{2}{c}{ Neither Agree nor } & Slightly Agree & Moderately Agree & Strongly Agree \\
Strongly Disagree & Disagree & Slightly Disagree & Disagree & 5 & 6 & 7 \\
1 & 2 & 3 & 4 & 0 & 0 & 0
\end{tabular}

The "end" is not near. People who think that earthquakes, wars, and famines mean God might be about to destroy the world are being foolish.

\begin{tabular}{ccccccc} 
& Moderately & \multicolumn{2}{c}{ Neither Agree nor } \\
Strongly Disagree & Disagree & Slightly Disagree & Disagree & Slightly Agree & Moderately Agree & Strongly Agree \\
1 & 2 & 3 & 4 & 5 & 6 & 7 \\
0 & 0 & 0 & 0 & 0 & 0 & 0
\end{tabular}


Every day, as our society becomes more lawless and bestial, a person's chances of being robbed, assaulted, and even murdered go up and up.

$\begin{array}{ccccccc} & \text { Moderately } & \text { Neither Agree nor } & & & \\ \text { Strongly Disagree } & \text { Disagree } & \text { Slightly Disagree } & \text { Disagree } & \text { Slightly Agree } & \text { Moderately Agree } & \text { Strongly Agree } \\ 1 & 2 & 3 & 4 & 5 & 6 & 7 \\ 0 & 0 & 0 & 0 & 0 & 0 & 0\end{array}$

Things are getting so bad, even a decent law-abiding person who takes sensible precautions can still become a victim of violence and crime.

\begin{tabular}{|c|c|c|c|c|c|c|}
\hline Strongly Disagree & $\begin{array}{l}\text { Moderately } \\
\text { Disagree }\end{array}$ & Slightly Disagree & $\begin{array}{c}\text { Neither Agree nor } \\
\text { Disagree }\end{array}$ & Slightly Agree & Moderately Agree & Strongly Agree \\
\hline 1 & 2 & 3 & 4 & 5 & 6 & 7 \\
\hline 0 & 0 & 0 & 0 & 0 & 0 & 0 \\
\hline
\end{tabular}

Our country is not falling apart or rotting from within.

$\begin{array}{ccccccc} & \text { Moderately } & \text { Neither Agree nor } & & & & \\ \text { Strongly Disagree } & \text { Disagree } & \text { Slightly Disagree } & \text { Disagree } & \text { Slightly Agree } & \text { Moderately Agree } & \text { Strongly Agree } \\ 1 & 2 & 3 & 4 & 5 & 6 & 7 \\ 0 & 0 & 0 & 0 & 0 & 0 & 0\end{array}$




\section{$\underline{\text { Schwartz Value Survev (adapted to be condensed for present research) }}$}

Please rate the importance of the following values as a life-guiding principle for you. Use the 8point scale in which 0 indicates that the value is opposed to your principles, 1 indicates that the value is not important for you, 4 indicates that the value is important, and 8 indicates that the value is of supreme importance for you.

\begin{tabular}{|c|c|c|c|c|c|c|c|c|c|}
\hline & $\begin{array}{c}\text { Opposed } \\
\text { to my } \\
\text { principles } \\
0\end{array}$ & $\begin{array}{c}\text { Not } \\
\text { important } \\
1\end{array}$ & 2 & 3 & $\begin{array}{c}\text { Important } \\
4\end{array}$ & 5 & 6 & 7 & $\begin{array}{c}\text { Of } \\
\text { supreme } \\
\text { importance } \\
8\end{array}$ \\
\hline Power & 0 & 0 & 0 & 0 & 0 & 0 & 0 & 0 & 0 \\
\hline Achievement & 0 & 0 & 0 & 0 & 0 & 0 & 0 & 0 & 0 \\
\hline Hedonism & 0 & O & 0 & O & 0 & 0 & 0 & O & 0 \\
\hline Stimulation & $\bigcirc$ & $\bigcirc$ & $\mathrm{O}$ & $\bigcirc$ & $\bigcirc$ & $\bigcirc$ & $\bigcirc$ & O & $\bigcirc$ \\
\hline Self-Direction & $\bigcirc$ & $\bigcirc$ & $\mathrm{O}$ & $\mathrm{O}$ & $\bigcirc$ & O & $\bigcirc$ & $\bigcirc$ & ○ \\
\hline Universalism & O & ○ & $\mathrm{O}$ & $\bigcirc$ & 0 & $\bigcirc$ & O & O & O \\
\hline Choose "Important" & ○ & ○ & $\mathrm{O}$ & $\bigcirc$ & ○ & O & $\mathrm{O}$ & O & ○ \\
\hline Benevolence & $\bigcirc$ & ○ & $\mathrm{O}$ & $\bigcirc$ & $\bigcirc$ & $\bigcirc$ & 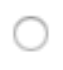 & O & $\bigcirc$ \\
\hline Tradition & O & $\bigcirc$ & $\mathrm{O}$ & $\bigcirc$ & $\bigcirc$ & $\bigcirc$ & $\bigcirc$ & O & 0 \\
\hline Conformity & $\bigcirc$ & $\bigcirc$ & $\mathrm{O}$ & O & $\bigcirc$ & O & $\mathrm{O}$ & $\bigcirc$ & ○ \\
\hline Security & $\bigcirc$ & $\bigcirc$ & $\mathrm{O}$ & $\bigcirc$ & $\bigcirc$ & $\bigcirc$ & $\bigcirc$ & $\bigcirc$ & $\bigcirc$ \\
\hline
\end{tabular}




\section{Ten Item Personality Inventory (TIPI)}

I see myself as...

\begin{tabular}{|c|c|c|c|c|c|c|c|}
\hline & $\begin{array}{l}\text { Disagree } \\
\text { strongly }\end{array}$ & $\begin{array}{l}\text { Disagree } \\
\text { moderately }\end{array}$ & $\begin{array}{l}\text { Disagree } \\
\text { a little }\end{array}$ & $\begin{array}{l}\text { Neither } \\
\text { agree nor } \\
\text { disagree }\end{array}$ & $\begin{array}{l}\text { Agree a } \\
\text { little }\end{array}$ & $\begin{array}{c}\text { Agree } \\
\text { moderately }\end{array}$ & $\begin{array}{l}\text { Agree } \\
\text { strongly }\end{array}$ \\
\hline $\begin{array}{l}\text { Extraverted, } \\
\text { enthusiastic. }\end{array}$ & $\bigcirc$ & O & 0 & $\bigcirc$ & $\bigcirc$ & $\mathrm{O}$ & O \\
\hline Critical, quarrelsome. & 0 & 0 & 0 & 0 & 0 & 0 & 0 \\
\hline $\begin{array}{l}\text { Dependable, self- } \\
\text { disciplined. }\end{array}$ & $\mathrm{O}$ & O & O & O & $\bigcirc$ & O & J \\
\hline \multirow[t]{2}{*}{ Anxious, easily upset. } & $\mathrm{O}$ & O & $\mathrm{O}$ & 0 & O & O & 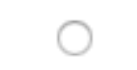 \\
\hline & $\begin{array}{l}\text { Disagree } \\
\text { strongly }\end{array}$ & $\begin{array}{l}\text { Disagree } \\
\text { moderately }\end{array}$ & $\begin{array}{l}\text { Disagree } \\
\text { a little }\end{array}$ & $\begin{array}{c}\text { Neither } \\
\text { agree nor } \\
\text { disagree }\end{array}$ & $\begin{array}{l}\text { Agree a } \\
\text { little }\end{array}$ & $\begin{array}{c}\text { Agree } \\
\text { moderately }\end{array}$ & $\begin{array}{l}\text { Agree } \\
\text { strongly }\end{array}$ \\
\hline $\begin{array}{l}\text { Open to new } \\
\text { experiences, complex. }\end{array}$ & $\bigcirc$ & $\bigcirc$ & $\bigcirc$ & O & $\bigcirc$ & O & 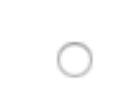 \\
\hline Reserved, quiet. & O & $\bigcirc$ & $\bigcirc$ & $\mathrm{O}$ & $\bigcirc$ & 0 & O \\
\hline Sympathetic, warm. & O & O & $\mathrm{O}$ & $\bigcirc$ & $\bigcirc$ & $\bigcirc$ & $\mathrm{O}$ \\
\hline \multirow[t]{2}{*}{ Disorganized, careless. } & $\bigcirc$ & $\bigcirc$ & $\bigcirc$ & $\mathrm{O}$ & $\mathrm{O}$ & 0 & $\mathrm{O}$ \\
\hline & $\begin{array}{l}\text { Disagree } \\
\text { strongly }\end{array}$ & $\begin{array}{l}\text { Disagree } \\
\text { moderately }\end{array}$ & $\begin{array}{l}\text { Disagree } \\
\text { a little }\end{array}$ & $\begin{array}{l}\text { Neither } \\
\text { agree nor } \\
\text { disagree }\end{array}$ & $\begin{array}{l}\text { Agree a } \\
\text { little }\end{array}$ & $\begin{array}{c}\text { Agree } \\
\text { moderately }\end{array}$ & $\begin{array}{l}\text { Agree } \\
\text { strongly }\end{array}$ \\
\hline $\begin{array}{l}\text { Choose "Disagree a } \\
\text { little" }\end{array}$ & O & O & O & $\mathrm{O}$ & $\mathrm{O}$ & O & \\
\hline $\begin{array}{l}\text { Calm, emotionally } \\
\text { stable. }\end{array}$ & O & $\bigcirc$ & $\mathrm{O}$ & O & $\mathrm{O}$ & $\bigcirc$ & C \\
\hline $\begin{array}{l}\text { Conventional, } \\
\text { uncreative. }\end{array}$ & O & O & O & $\bigcirc$ & 0 & $\bigcirc$ & C \\
\hline
\end{tabular}




\section{Beck Anxiety Inventory}

Please rate how much you've been bothered by each of the following symptoms over the past week.

\begin{tabular}{|c|c|c|c|c|}
\hline & $\begin{array}{c}\text { Not at all } \\
0\end{array}$ & $\begin{array}{c}\text { Mildly, but it didn't } \\
\text { bother me much } \\
1\end{array}$ & $\begin{array}{l}\text { Moderately-it wasn't } \\
\text { pleasant at times } \\
2\end{array}$ & $\begin{array}{c}\text { Severely-I could barely } \\
\text { stand it } \\
3\end{array}$ \\
\hline Unable to relax & ○ & O & $\bigcirc$ & ○ \\
\hline Fear of the worst happening & ○ & ○ & $\circ$ & $\circ$ \\
\hline Terrified & ○ & 0 & 0 & ○ \\
\hline Nervous & ○ & ○ & ○ & ○ \\
\hline Feeling of choking & 0 & O & ० & ○ \\
\hline Choose "Moderately" & O & 0 & 0 & ○ \\
\hline Fear of losing control & 0 & 0 & $\circ$ & ० \\
\hline Difficulty breathing & 0 & ○ & 0 & ○ \\
\hline Fear of dying & O & $\circ$ & ○ & ○ \\
\hline $\begin{array}{l}\text { Indigestion or discomfort in } \\
\text { abdomen }\end{array}$ & ○ & O & 0 & ○ \\
\hline
\end{tabular}




\section{Subjective Distress Caused by COVID-19 (Impact of Event Scale) - Adapted to COVID-19 Context}

On March 11th, 2020 the World Health Organization officially declared the COVID-19, a viral disease that has swept the globe, a pandemic.

Below is a list of comments made by people after stressful life events. Please read each item, indicating how frequently these comments were true for you DURING THE PAST SEVEN DAYS. If they did not occur during that time, please mark the "not at all" column.

\begin{tabular}{|c|c|c|c|c|}
\hline & Not At All & Rarely & Sometimes & Often \\
\hline $\begin{array}{l}\text { I thought about the virus when I } \\
\text { didn't mean to. }\end{array}$ & $\bigcirc$ & 0 & 0 & 0 \\
\hline $\begin{array}{l}\text { I avoided letting myself get upset } \\
\text { when I thought about the virus or } \\
\text { was reminded of the virus. }\end{array}$ & $\circ$ & 0 & 0 & 0 \\
\hline $\begin{array}{l}\text { I tried to remove the virus from } \\
\text { my memory. }\end{array}$ & 0 & 0 & 0 & 0 \\
\hline $\begin{array}{l}\text { I had trouble falling asleep or } \\
\text { staying asleep, because thoughts } \\
\text { about the virus came into my } \\
\text { mind. }\end{array}$ & 0 & 0 & 0 & 0 \\
\hline $\begin{array}{l}\text { I had waves of strong feelings } \\
\text { about the virus. }\end{array}$ & 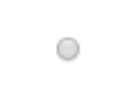 & $\bigcirc$ & 0 & 0 \\
\hline I had dreams about the virus. & $\odot$ & $\bigcirc$ & $\odot$ & $\bigcirc$ \\
\hline $\begin{array}{l}\text { I stayed away from reminders of } \\
\text { the virus. }\end{array}$ & 0 & 0 & 0 & 0 \\
\hline $\begin{array}{l}\text { I felt as if the virus hadn't } \\
\text { happened or it wasn't real. }\end{array}$ & 0 & 0 & 0 & 0 \\
\hline I tried not to talk about the virus. & $\odot$ & $\bigcirc$ & $\bigcirc$ & $\bigcirc$ \\
\hline $\begin{array}{l}\text { Pictures about the virus popped } \\
\text { into my mind. }\end{array}$ & 0 & 0 & 0 & 0 \\
\hline $\begin{array}{l}\text { Other things kept making me } \\
\text { think about the virus. }\end{array}$ & $\odot$ & 0 & 0 & 0 \\
\hline $\begin{array}{l}\text { I was aware that I still had a lot } \\
\text { of feelings about the virus, but I } \\
\text { didn't deal with them. }\end{array}$ & 0 & 0 & 0 & 0 \\
\hline $\begin{array}{l}\text { I tried not to think about the } \\
\text { virus. }\end{array}$ & $\odot$ & 0 & 0 & 0 \\
\hline $\begin{array}{l}\text { Any reminder brought back } \\
\text { feelings about the virus. }\end{array}$ & $\circ$ & $\bigcirc$ & $\bigcirc$ & $\bigcirc$ \\
\hline $\begin{array}{l}\text { My feelings about the virus were } \\
\text { kind of numb. }\end{array}$ & $\bigcirc$ & $\bigcirc$ & $\bigcirc$ & $\bigcirc$ \\
\hline
\end{tabular}




\section{Study 2 - Detailed Description of Sample, Measures, and Results}

Sample. Five-hundred and fifty American participants recruited from Mturk completed the survey on March $26^{\text {th }}, 2020$. After pre-registered exclusions, 537 participants (256 male, 278 female, 3 other; $M_{\text {age }}=39.25, S D_{\text {age }}=12.97 ; 77.8 \%$ White, $11.7 \%$ Black or African American, $5.6 \%$ Latinx/Hispanic) were included in our analyses. We pre-registered a desired sample of at least $\sim 500$ participants and oversampled (i.e., $\mathrm{N}=550$ ) in anticipation of exclusions. We aimed for a slightly larger sample size than Study 1 to ensure that we followed guidelines of having at least 5-10 cases per parameter in our pre-determined CFA and SEM models (in this case at least 105-210 for our CFA model and 455-910 for our SEM model; see Kline, 2011). See http://aspredicted.org/blind.php? $\mathrm{x}=5 \mathrm{uu} 4 \mathrm{kf}$ _for more information.

\section{Measures}

All scores represent the means of all items, with the exception of the Beck Anxiety Inventory, the Positive and Negative Affect scales, and the Impact of COVID-19 Event scales which were summed.

Integrative COVID-19 Threat Scale. We assessed realistic threat $(\alpha=.73)$ and symbolic threat $(\alpha=.86)$ using the 10 -items we focused on in Study 1.

Convergent Validity. We used scales identical to Study 1 to assess the need for cognitive closure $(\alpha=.89)$, the belief in a dangerous world $(\alpha=.89)$, values related to conservation $(\alpha=.92)$, emotional stability $(r=.64)$.

Divergent Validity. We used scales identical to Study 1 to assess values related to openness to change $(r=.29)$, values related to self-enhancement $(\alpha=.59)$, values related to selftranscendence $(r=.20)$, extraversion $(r=.64)$, agreeableness $(r=.39)$, conscientiousness $(r=.52)$, openness to experience $(r=.37)$. 


\section{Criterion Validity.}

Psychological Distress. We used scales identical to Study 1 to assess general anxiety $(\alpha=.89)$ and subjective distress caused by COVID-19 (i.e., COVID-19 impact intrusion $(\alpha=.86)$ and COVID-19 impact avoidance $(\alpha=.79))$

Psychological Well-Being. We assessed people's general satisfaction with life using Diener's five-item scale (Diener, Emmons, Larsen, Griffin, 1985). Participants rated each item on a scale anchored from 1 (Strongly Disagree) and 7 (Strongly Agree). A sample item included: "In most ways my life is close to my ideal"; $\alpha=.89$ ).

Positive and Negative Affect. Participants rated their positive affect $(\alpha=.91)$ and negative affect $(\alpha=.92)$ at the time of writing the survey using the PANAS short form (Watson, Clark, \& Tellegen, 1988). Participants rated to what extent they felt each emotion at the time of completing the survey with scales anchored at 1 (Very Slightly or Not at All) and 7 (Extremely).

\section{Public Health Behaviors.}

Adherence to Socially Restrictive Public Health (CDC) Behaviors. We adapted two items from Everette and colleagues (2020) to assess how much people reported adhering to the socially restrictive practices recommended by the CDC for preventing the spread of the COVID19 virus. Participants rated how much they were doing each of the following on a scale anchored at 1 (Not at All) and 5 (Always): "Staying at home and avoiding all social contact"; "Avoiding public gatherings" $(r=.54)$.

Adherence to Non-Restrictive Public Health (CDC) Behaviors. We adapted one item from Everette and colleagues (2020) to assess how much people reported adhering to a non-restrictive (sanitary) practice recommended by the CDC for preventing the spread of the COVID-19 virus. Specifically, participants rated how much they were "Washing your hands often for at least 20 
seconds especially after being in a public space" on a scale anchored at 1 (Not at All) and 5 (Always).

Support for Socially Restrictive Public Health Behaviors to Reduce Spread of COVID19. We developed 4 items to assess support for restrictive policies aimed at reducing the spread of COVID-19. Participants rated their agreement with the following statements: "The social distancing restrictions being put into place to stop the spread of Covid-19 are doing more harm than good" (reverse coded); "We need to prioritize going back to our normal routines as soon as possible, regardless of COVID-19's spread" (reverse coded); "Right now the most important thing we can do is take all measures possible to stop the spread of COVID-19"; "It is essential that we strictly practice social distancing as a nation, until health care experts say otherwise". Participants rated agreement to each item on a scale anchored from 1 (Strongly Disagree) to 7 (Strongly Agree) $(\alpha=.89)$.

Social (National) Identity Affirming Behaviors in Isolation. We developed three items to assess how much people engaged in behaviors aimed at affirming their social (national) identity while still conforming to restrictive social distancing. Participants rated how much they were doing each of these behaviors on a scale anchored at 1 (Not at All) and 5 (Always): "I watch or listen to music, videos, movies, or re-plays of cultural events that remind me most of American culture"; "I share things with my friends and family on the phone or through social media that remind us of what life was like in America before COVID-19"; "I engage in behaviors that I associate with American identity (e.g., I cook foods that make me feel American)" ( $\alpha=.79)$.

Identity-Non-Specific Social Behaviors in Isolation. We developed two items to assess how much people engaged in socially affirming behaviors that are not directly tied to social 
(national) identity. Participants rated how much they were doing each of these behaviors on a scale anchored at 1 (Not at All) and 5 (Always): "I find creative new ways to maintain my old routines (e.g., video chats with family and friends; online exercise classes; cultural activities online)"; "I engage with "virtual communities" through social media and online groups to replace the in-person communities I can no longer be a part of" $(r=.47)$.

\section{Results}

\section{Confirmatory Factor Analysis}

We conducted confirmatory factor analysis (CFA; Byrne, 1994) to test whether a twofactor solution representing symbolic threat and realistic threat perceptions of COVID-19 fit our data well (See Figure 1). Overall, the two-factor model had acceptable model fit indices: comparative fit index $(C F I)=.94$, standard root mean square intervals $(S R M R)=.06$, root mean square error Approximation $(R M S E A)=.08,90 \% \mathrm{CI}[.07, .09], B I C=11852.71, \chi^{2}=144.03 .08(\mathrm{Hu}$ \& Bentler, 1999; Byrne, 1994; Steiger, 1990) and no negative error variances or improper solutions. We compared the two-factor model to a one-factor model which did not differentiate between symbolic threat or realistic threat $(C F I=.75, S R M R=.12, R M S E A=.16,90 \% \mathrm{CI}[.15, .17]$,

$\left.B I C=12199.03, \chi^{2}=496.63\right)$. The one-factor model had inferior model fit, $\chi_{\text {dif }}^{2}=-352.60$, $p<.001$.

\section{Convergent and divergent validity}

Overall, results were consistent with Study 1, supporting both convergent (H1) and divergent $(\mathrm{H} 2)$ validity. We report in Table 6 descriptive statistics and inter-item correlations for the variables pertaining to convergent and divergent validity.

\section{(Table 6 is presented in Main Manuscript)}


Overall, we found a consistent pattern of results with Study 1. As in Study 1, the perceived threat of COVID-19 (combining both dimensions) was positively associated with the need for cognitive closure, belief in a dangerous world, values related to conservation, and was negatively associated with emotional stability. Supporting divergent validity, threat to COVID19 (combining both dimensions) was not significantly associated with the other dimensions of Schwartz's value scale of the Ten-Item-Personality Invention with the exception of a weak yet significant correlation with self-enhancement values.

Our results were mostly consistent when we examined the associations for each threat dimension separately. Overall, conservation was robustly associated with symbolic threat but not realistic threat. However, as in Study 1, realistic threat was significantly related to valuing security $(r(537)=.11, p=.010)$, but not valuing tradition, or conformity. Symbolic threat in contrast was significantly associated with valuing tradition and conformity (all $p s<.001$ ), but not valuing security $(r(537)=.02, p=.657$. Consistent with Study 1 , we again observed unanticipated significant associations between symbolic threat and values relating to self-enhancement. We also observed an association between realistic threat and values relating self-transcendence.

\section{Criterion Validity}

In Table 7 we summarize descriptive statistics for all nine criterion outcomes, as well as their zero-order correlations with realistic and symbolic threat.

\section{(Table 7 is presented in Main Manuscript)}

We examined the association between symbolic threat and realistic threat, and all criterion outcomes of interest simultaneously within one structural equation path model (SEM; Byrne, 1994). This analysis was conducted using the Lavaan package in R (Rosseel, 2012). In 
the model, we regressed each of the eleven criterion outcomes onto both threat dimensions. We allowed the two threat dimensions to covary, and, the elven psychological response outcomes to covary. The model was fully saturated, $\chi^{2}(0)=0$. Results for the SEM path analyses are summarized in Table 8. All results described below refer to relations observed in the full SEM model.

Psychological distress, well-being, and affect (H3). Replicating Study 1, realistic threat was significantly positively associated with anxiety and COVID-19 impact intrusion, while symbolic threat was significantly positively associated with COVID-19 impact avoidance and COVID-19 impact intrusion. In contrast to Study 1, realistic threat was also associated with COVID-19 impact avoidance, while symbolic threat was also significantly associated with anxiety.

Providing partial support for $\mathrm{H} 3$, realistic (but not symbolic) threat was negatively associated with life satisfaction. Symbolic and realistic threat were positively associated with negative affect. We observed an unanticipated significant positive relation between symbolic threat and positive affect. To probe this effect further, we conducted an exploratory parallelmediation analysis in which we tested whether experiencing symbolic threat was associated with greater positive affect because of symbolic threat being associated with (1) reductions in adherence to socially restrictive CDC guidelines, or, increases in social (national) identity affirming behaviors in isolation. Both potential mediators were entered simultaneously in parallel in the model. There was no significant indirect effect of symbolic threat on positive affect through reduced engagement in socially restrictive $\mathrm{CDC}$ behaviors (indirect effect $=.12,95 \% \mathrm{CI}$ $[-.02, .30])$. However, by promoting greater engagement in social (national) identity affirming 
behaviors, symbolic threat appeared to indirectly relate to more positive affect (indirect effect $=$ $.66,95 \%$ CI $[.27,1.12])$.

Support and adherence with socially restrictive and non-restrictive public health

behaviors (H4). Realistic threat was significantly and positively associated with support of and self-reported adherence to socially restrictive public health behaviors (i.e., social distancing) and non-restrictive health behaviors (i.e., handwashing). In contrast, symbolic threat was significantly and negatively associated with support and adherence to socially restrictive public health behaviors, and was unrelated to non-restrictive health behaviors.

Social (national) identity affirmation in isolation (H5). Symbolic (but not realistic) threat was positively associated with engaging in behaviors (while in isolation) to affirm one's (national) identity (e.g., cooking food subjectively associated with America). In contrast, realistic threat (but not symbolic threat) was associated with engagement in identity-non-specific social behaviors which were routine prior to the pandemic (e.g., communication with family, exercise groups, or local communities).

(Table 8 is presented in Main Manuscript 


\section{Study 2 Scales (Qualtrics Survey)}

*Note. In this survey we also included: the TIPI, the Schwartz value scale, the Need for Cognitive Closure Scale, the Belief in a Dangerous World Scale, The Beck Depression Inventory, and The Impact of Event Scale. We do not show these scales again because they were presented in identical fashion to Study 1.

\section{Integrated COVID-19 Threat Scale (Final 10 item Version used in Study 2 and 3)}

On March 11th, 2020 the World Health Organization officially declared the COVID-19, a viral disease that has swept the globe, a pandemic. How much of a threat, if any, is the coronavirus outbreak for...

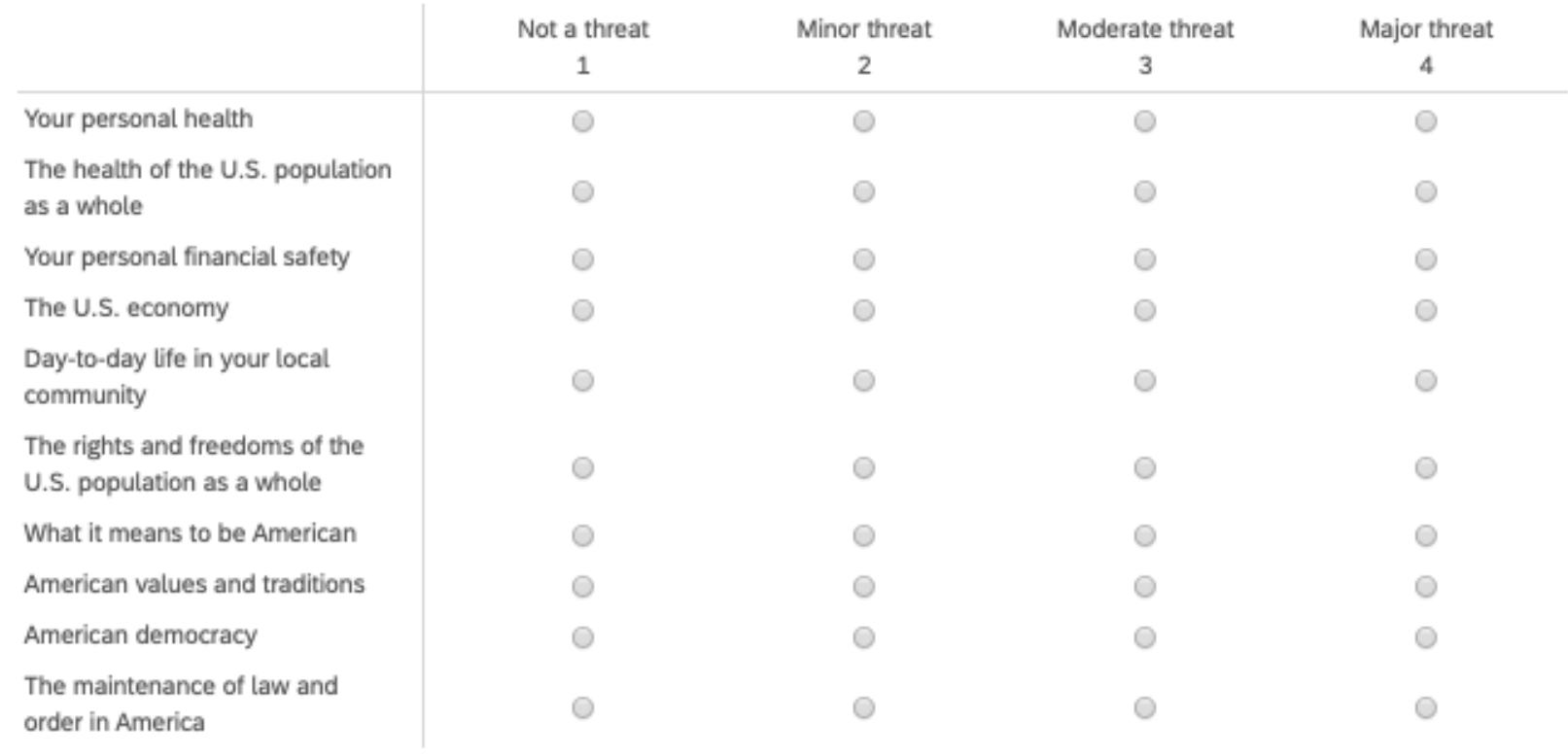




\section{Life Satisfaction (Psychological Well-Being)}

Below are five statements that you may agree or disagree with. Please indicate your agreement with each item. Please be open and honest in your responding.

\begin{tabular}{|c|c|c|c|c|c|c|c|}
\hline & $\begin{array}{c}\text { Strongly } \\
\text { disagree } \\
1\end{array}$ & $\begin{array}{c}\text { Disagree } \\
2\end{array}$ & $\begin{array}{c}\text { Slightly } \\
\text { disagree } \\
3\end{array}$ & $\begin{array}{c}\text { Neither } \\
\text { agree nor } \\
\text { disagree } \\
4\end{array}$ & $\begin{array}{c}\text { Slightly } \\
\text { agree } \\
5\end{array}$ & $\begin{array}{c}\text { Agree } \\
6\end{array}$ & $\begin{array}{c}\text { Strongly } \\
\text { agree } \\
7\end{array}$ \\
\hline $\begin{array}{l}\text { In most ways my life is close to } \\
\text { my ideal }\end{array}$ & $\bigcirc$ & 0 & 0 & 0 & 0 & 0 & 0 \\
\hline $\begin{array}{l}\text { The conditions of my life are } \\
\text { excellent }\end{array}$ & 0 & 0 & 0 & 0 & 0 & 0 & 0 \\
\hline I am satisfied with my life & $\bigcirc$ & $\bigcirc$ & $\bigcirc$ & $\odot$ & $\bigcirc$ & $\bigcirc$ & $\odot$ \\
\hline $\begin{array}{l}\text { So far I have gotten the } \\
\text { important things I want in life }\end{array}$ & 0 & 0 & 0 & 0 & 0 & 0 & 0 \\
\hline $\begin{array}{l}\text { If I could live my life over, I would } \\
\text { change almost nothing }\end{array}$ & 0 & 0 & 0 & 0 & 0 & 0 & 0 \\
\hline
\end{tabular}




\section{Positive and Negative Affect}

This scale consists of a number of words that describe different feelings and emotions. Read each item and then mark the appropriate answer. Indicate to what extent you feel this way right now, that is, at the present moment.

\begin{tabular}{|c|c|c|c|c|c|}
\hline & $\begin{array}{c}\text { Very slightly or not } \\
\text { at all } \\
1\end{array}$ & $\begin{array}{c}\text { A little } \\
2\end{array}$ & $\begin{array}{c}\text { Moderately } \\
3\end{array}$ & $\begin{array}{c}\text { Quite a bit } \\
\qquad 4\end{array}$ & $\begin{array}{c}\text { Extremely } \\
5\end{array}$ \\
\hline Interested & 0 & ○ & 0 & 0 & 0 \\
\hline Distressed & 0 & ○ & ○ & ○ & ○ \\
\hline Excited & 0 & 0 & ○ & 0 & 0 \\
\hline Upset & ○ & 0 & ○ & $\circ$ & $\circ$ \\
\hline Strong & ○ & ○ & ○ & ○ & ○ \\
\hline Guilty & 0 & 0 & ○ & $\circ$ & 0 \\
\hline \multirow[t]{2}{*}{ Scared } & 0 & 0 & 0 & 0 & ○ \\
\hline & $\begin{array}{c}\text { Very slightly or not } \\
\text { at all } \\
1\end{array}$ & $\begin{array}{c}\text { A little } \\
2\end{array}$ & $\begin{array}{c}\text { Moderately } \\
3\end{array}$ & $\begin{array}{c}\text { Quite a bit } \\
4\end{array}$ & $\begin{array}{c}\text { Extremely } \\
5\end{array}$ \\
\hline Hostile & $\circ$ & ○ & ○ & ○ & ○ \\
\hline Enthusiastic & ○ & ○ & ○ & ○ & ○ \\
\hline Proud & 0 & 0 & ○ & 0 & 0 \\
\hline Irritable & 0 & 0 & ○ & ○ & ○ \\
\hline Alert & ○ & 0 & ○ & ○ & ○ \\
\hline Ashamed & $\circ$ & 0 & ○ & $\circ$ & ○ \\
\hline \multirow[t]{2}{*}{ Inspired } & 0 & 0 & ○ & ○ & ○ \\
\hline & $\begin{array}{c}\text { Very slightly or not } \\
\text { at all } \\
1\end{array}$ & $\begin{array}{c}\text { A little } \\
2\end{array}$ & $\begin{array}{c}\text { Moderately } \\
3\end{array}$ & $\begin{array}{c}\text { Quite a bit } \\
4\end{array}$ & $\begin{array}{c}\text { Extremely } \\
5\end{array}$ \\
\hline Nervous & 0 & ○ & ○ & $\circ$ & ○ \\
\hline Determined & ○ & ○ & ○ & ○ & ○ \\
\hline Attentive & 0 & 0 & ○ & ○ & ○ \\
\hline Jittery & 0 & 0 & ○ & ○ & ○ \\
\hline Active & 0 & ○ & ○ & ○ & ○ \\
\hline Afraid & 0 & 0 & ○ & ○ & ○ \\
\hline
\end{tabular}




\section{Adherence to Socially Restrictive and Non-Restrictive Public Health Behaviors from the}

Centers for Infectious Diseases (CDC)

Here are several behaviors which the Centers for Disease Control and Prevention (CDC) recommends for reducing the spread of COVID-19. Please rate how much you are doing each the following behaviors.

\begin{tabular}{|c|c|c|c|c|c|}
\hline & $\begin{array}{c}\text { Not at all } \\
1\end{array}$ & $\begin{array}{c}\text { Rarely } \\
2\end{array}$ & $\begin{array}{c}\text { Sometimes } \\
3\end{array}$ & $\begin{array}{c}\text { Often } \\
4\end{array}$ & $\begin{array}{c}\text { Always } \\
5\end{array}$ \\
\hline $\begin{array}{l}\text { Washing your hands often for at } \\
\text { least } 20 \text { seconds especially after } \\
\text { being in a public place. }\end{array}$ & 0 & 0 & 0 & 0 & 0 \\
\hline Avoiding public gatherings & $\bigcirc$ & $\bigcirc$ & $\odot$ & $\bigcirc$ & 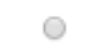 \\
\hline $\begin{array}{l}\text { Staying at home and avoiding all } \\
\text { social contact }\end{array}$ & $\bigcirc$ & $\bigcirc$ & $\bigcirc$ & $\bigcirc$ & $\bigcirc$ \\
\hline
\end{tabular}




\section{Support for Socially Restrictive Public Health Behaviors to Reduce Spread of COVID-19}

Please rate your agreement with the following statements.

\begin{tabular}{|c|c|c|c|c|c|c|c|}
\hline & $\begin{array}{c}\text { Strongly } \\
\text { disagree } \\
1\end{array}$ & 2 & 3 & $\begin{array}{c}\text { Neutral } \\
4\end{array}$ & 5 & 6 & $\begin{array}{l}\text { Strongly } \\
\text { agree } \\
7\end{array}$ \\
\hline $\begin{array}{l}\text { The social distancing restrictions } \\
\text { being put into place to stop the } \\
\text { spread of COVID-19 are doing } \\
\text { more harm than good. }\end{array}$ & 0 & 0 & 0 & 0 & 0 & 0 & 0 \\
\hline $\begin{array}{l}\text { We need to prioritize going back } \\
\text { to our normal routines as soon as } \\
\text { possible, regardless of COVID- } \\
19 \text { 's spread. }\end{array}$ & 0 & 0 & 0 & 0 & 0 & 0 & 0 \\
\hline $\begin{array}{l}\text { Right now the most important } \\
\text { thing we can do is take all } \\
\text { measures possible to stop the } \\
\text { spread of COVID-19. }\end{array}$ & 0 & 0 & 0 & 0 & 0 & 0 & 0 \\
\hline $\begin{array}{l}\text { It is essential that we strictly } \\
\text { practice social distancing as a } \\
\text { nation, until health care experts } \\
\text { say otherwise. }\end{array}$ & 0 & 0 & 0 & 0 & 0 & 0 & 0 \\
\hline
\end{tabular}


Social (National) Identity Affirming Behaviors and Identity Non-Specific Social Behaviors in Isolation

Here are several behaviors which you might have started doing during the COVID-19 pandemic. Please rate how much you are doing each the following behaviors.

\begin{tabular}{|c|c|c|c|c|c|}
\hline & $\begin{array}{c}\text { Not at all } \\
1\end{array}$ & $\begin{array}{c}\text { Rarely } \\
2\end{array}$ & $\begin{array}{c}\text { Sometimes } \\
3\end{array}$ & $\begin{array}{c}\text { Often } \\
4\end{array}$ & $\begin{array}{c}\text { Always } \\
5\end{array}$ \\
\hline $\begin{array}{l}\text { I find creative new ways to } \\
\text { maintain my old routines (e.g., } \\
\text { video chats with family and } \\
\text { friends; online exercise classes; } \\
\text { cultural activities online). }\end{array}$ & 0 & 0 & 0 & 0 & 0 \\
\hline $\begin{array}{l}\text { I watch or listen to music, videos, } \\
\text { movies, or re-plays of cultural } \\
\text { events that remind me the most } \\
\text { of American culture. }\end{array}$ & 0 & 0 & 0 & 0 & 0 \\
\hline $\begin{array}{l}\text { I share things with my friends } \\
\text { and family on the phone or } \\
\text { through social media that remind } \\
\text { us of what life was like in } \\
\text { America before COVID-19. }\end{array}$ & 0 & 0 & 0 & 0 & 0 \\
\hline $\begin{array}{l}\text { I engage with "virtual } \\
\text { communities" through social } \\
\text { media and online groups to } \\
\text { replace the in-person } \\
\text { communities I can no longer be a } \\
\text { part of. }\end{array}$ & 0 & 0 & 0 & 0 & 0 \\
\hline $\begin{array}{l}\text { I engage in behaviors that I } \\
\text { associate with American identity } \\
\text { (e.g., I cook foods that make me } \\
\text { feel American). }\end{array}$ & 0 & 0 & 0 & 0 & 0 \\
\hline
\end{tabular}


Emotion Regulation Questionnaire (Not focused on in paper, see OSF data and Syntax; Neither factor of the ERQ was associated with either symbolic or realistic threat)

\begin{tabular}{|c|c|c|c|c|c|c|c|}
\hline & $\begin{array}{l}\text { Strongly } \\
\text { disagree } \\
\quad 1\end{array}$ & 2 & 3 & $\begin{array}{c}\text { Neutral } \\
4\end{array}$ & 5 & 6 & $\begin{array}{c}\text { Strongly agree } \\
7\end{array}$ \\
\hline $\begin{array}{l}\text { When I want to feel more positive } \\
\text { emotion (such as joy or amusement), I } \\
\text { change what I'm thinking about. }\end{array}$ & 0 & 0 & 0 & 0 & $\circ$ & 0 & 0 \\
\hline I keep my emotions to myself. & 0 & $\circ$ & 0 & 0 & 0 & 0 & O \\
\hline $\begin{array}{l}\text { When I want to feel less negative } \\
\text { emotion (such as sadness or anger), I } \\
\text { change what I'm thinking about. }\end{array}$ & O & $\circ$ & 0 & $\odot$ & $\bigcirc$ & ○ & 0 \\
\hline $\begin{array}{l}\text { When I am feeling positive emotions, I } \\
\text { am careful not to express them. }\end{array}$ & 0 & 0 & $\circ$ & ○ & $\circ$ & $\circ$ & $\circ$ \\
\hline $\begin{array}{l}\text { When I'm faced with a stressful } \\
\text { situation, I make myself think about it } \\
\text { in a way that helps me stay calm. }\end{array}$ & $\circ$ & 0 & 0 & 0 & 0 & 0 & 0 \\
\hline $\begin{array}{l}\text { I control my emotions by not } \\
\text { expressing them. }\end{array}$ & 0 & 0 & $\circ$ & $\circ$ & $\circ$ & $\circ$ & $\circ$ \\
\hline $\begin{array}{l}\text { When I want to feel more positive } \\
\text { emotion, I change the way I'm thinking } \\
\text { about the situation. }\end{array}$ & 0 & $\circ$ & 0 & 0 & 0 & $\circ$ & 0 \\
\hline $\begin{array}{l}\text { I control my emotions by changing the } \\
\text { way I think about the situation I'm in. }\end{array}$ & O & 0 & 0 & 0 & 0 & 0 & $\circ$ \\
\hline $\begin{array}{l}\text { When I am feeling negative emotions, I } \\
\text { make sure not to express them. }\end{array}$ & ○ & $\circ$ & 0 & $\circ$ & $\circ$ & $\circ$ & $\circ$ \\
\hline $\begin{array}{l}\text { When I want to feel less negative } \\
\text { emotion, I change the way I'm thinking } \\
\text { about the situation. }\end{array}$ & 0 & 0 & 0 & 0 & 0 & 0 & 0 \\
\hline
\end{tabular}




\section{Study 3 - Detailed Description of Sample, Measures, and Results}

Sample. Three hundred and eleven participants recruited from Mturk completed the survey on March $27^{\text {th }}-28^{\text {th }} 2020$. Three hundred and ten participants had completed the study one week prior (T1) on March $19^{\text {th }}-20^{\text {th }}$ (i.e., participants from Study 1). After pre-registered exclusions, our sample consisted of 259 participants (122 male, $137 \mathrm{female} ; M_{\text {age }}=42.17$, $S D_{a g e}=13.93 ; 81.9 \%$ White, 9.3\% Black or African American, $3.5 \%$ Latinx/Hispanic). In terms of sample-size we were limited to being able to recruit as many participants who also completed the T1 survey. Because of the urgency of producing this manuscript as quickly as possible so that researchers can have access to our measure we limited the data collection time window to 24 hours. See our pre-registration https://aspredicted.org/blind.php? $\mathrm{x}=2 \mathrm{ed} 62 \mathrm{c}$ for more information.

\section{Measures}

All scores represent the means of all items, with the exception of the Beck Anxiety Inventory, the Positive and Negative Affect scales, and the Impact of COVID-19 Event (subjective distress) scales which were summed. Sales were framed with respect to how participants felt over the past week (or last seven days). The only exceptions to this were the Life Satisfaction Scale, the Support for Restrictive Policies to Prevent COVID-19 scale, and the Integrated COVID-19 threat scale which were framed in the present tense.

Integrative COVID-19 Threat Scale (T1 and T2). Amongst the sample who completed both T1 and T2, we assessed realistic threat $\left(\alpha_{\mathrm{t} 1}=.75 ; \alpha_{\mathrm{t} 2}=.76\right)$ and symbolic threat $(\alpha$ $\left.{ }_{\mathrm{t} 1}=.86 ; \alpha_{\mathrm{t} 2}=.86\right)$ using the ten-item Integrated COVID-19 Threat Scale.

\section{Criterion Validity.}

Psychological Distress. As in Study 2 we used the Beck anxiety scale to assess general anxiety except that we asked participants to report on symptoms they experienced over the past 
week $(\alpha=.89)$. As in Study 2 participants also completed the COVID-19 impact intrusion $(\alpha=.90)$ and COVID-19 impact avoidance $(\alpha=.81)$ subscales of the Impact of Event scale which assesses subjective distress: Participants responded were asked to "indicate to what extent you have felt this way during the past week".

Psychological Well-Being. Identical to Study 2, we assessed people's general satisfaction with life using Diener's five-item scale (Diener, et al., 1985; $\alpha=.91$ ).

Positive and Negative Affect. As in Study 2, Participants rated their positive affect ( $\alpha=$ .91) and negative affect $(\alpha=.92)$ using the PANAS short form (Watson, et al., 1988), but with respect to "what extent you felt this way during the past week".

Public Health Behaviors. We assessed self-reported adherence to socially restrictive public health $(C D C)$ behaviors $(r=.63)$, self-reported adherence to non-restrictive public health (CDC) behaviors, and support for socially restrictive public health behaviors $(\alpha=.89)$ using the same scales from Study 2. The only exception was that when reporting adherence to CDC guidelines, participants rated how much they did each behavior "over the past week".

Social (National) Identity Affirming Behaviors in Isolation. We used the same 3-items as in Study 2, except that items were framed with respect to how much participants did each behavior "over the past week" $(\alpha=.81)$.

Identity-Non-Specific Social Behaviors in Isolation. We used the same 2-items as in Study 2, except that items were framed with respect to how much participants did each behavior "over the past week" $(\alpha=.45)$.

\section{Results}

Scale Invariance. We examined the invariance of both subscales using longitudinal confirmatory factor analysis (Meredith, 1993) with the SemTools package in R (Jorgensen, 
2019). Because we confirmed there being two distinct factors in Study 2, and because all our analyses focus on the separate sub-scales we explored the invariance of each sub-scale separately.

To assess whether our scale items assessed the same construct over time (configural invariance) we allowed the factor loadings, item intercepts, residual item variances, and the variance of the latent means to freely co-vary across groups. The latent means were set to equal zero. To assess whether the scale had the same meaning overtime (metric invariance) we fixed the factor loadings to be equivalent across groups and assessed the resulting change in model fit relative to the configural (base-line) model. To justify mean comparisons across time (scalar invariance) we additionally constrained the item intercepts and fixed the latent means of one group to 0 while estimating the latent means in the other group: we compared the scalar invariance model to the metric invariance model. Lastly, in an additional model, we constrained the latent means to be equivalent across groups and compared this to the scalar invariance model. When comparing models at each step of invariance assessment, we followed the best practices reviewed by Putnick and Bornstein (2016). Specifically, we tested whether the change in chi-square $\left(\chi^{2}\right)$ between models significantly differed, and we examined at least two alternative fit indices: the Comparative Fit Index (CFI)) and the Root Mean Square Error of Approximation (RMSEA). Two models of comparison were considered not to significantly differ in fit when (1) the $\chi^{2}$ change between models was non-significant (e.g., Byrne, Shavelson, \& Muthén, 1989 ; Reise, Widaman, \& Pugh, 1993), and (2) the change in CFI between models did not exceed a deterioration of >-.01 (note that larger CFIs mean better fit), combined with an RMSEA change that did not increase more than .015 (note that lower RMSEAs indicate better fit; Chen, 2007). As illustrated in Table 9 we find evidence for configural, metric and scalar 
invariance, as well as equivalence in the latent means, for both the symbolic and realistic threat scales (all $\Delta \mathrm{X}^{2}$ n.s ; all $\Delta$ CFIs did not indicate deterioration of more than -.01; all $\Delta$ RMSEAs did not increase more than an increase of .015). RMSEAs were actually lower in the more restricted (invariant) models.

\section{(Table 9 is Presented in Main Manuscript)}

\section{Criterion Validity}

In Table 10 we summarize descriptive statistics for all eleven criterion outcomes (assessed at T2), as well as their zero-order correlations with realistic and symbolic threat (assessed at T1).

\section{(Table 10 is Presented in Main Manuscript)}

Using SEM, we examined the association between symbolic threat and realistic threat (at T1), and all criterion outcomes assessed one week later, simultaneously in one model. We covaried symbolic and realistic threat in the model, and, we covaried the eleven psychological response outcomes in the model. The model was fully saturated, $\chi^{2}(0)=0$. Results for the SEM path analyses are summarized in Table 11. We focus on results from the SEM analysis when describing our findings below.

\section{(Table 11 is Presented in Main Manuscript)}

\section{Psychological distress, well-being, and affect (H3).}

Realistic threat (at T1) was associated with COVID-19 impact intrusion and anxiety, but was not associated with COVID-19 impact avoidance, over the course of the following week (measured at T2). Symbolic threat was also significantly positively associated with COVID-19 impact intrusion, general anxiety, and additionally, impact avoidance. 
Both types of threat (at T1) were positively associated with negative affect experienced over the course of a subsequent week. Replicating Study 2, realistic threat (but not symbolic threat) was negatively associated with life satisfaction. As in Study 2, we again observed an unanticipated significant positive relation between symbolic threat and positive affect. Exploratory parallel-mediation analysis (entering self-reported adherence to socially restrictive public health behaviors, and self-reported social identity affirming behaviors simultaneously into one model) indicated a significant indirect effect of symbolic threat on positive affect through greater engagement in social (national) identity affirming behaviors (indirect effect $=.67$, $95 \%[.17,1.21]$ ), but not through lower adherence to socially restrictive CDC adherence (indirect effect $=.02,95 \%[-.26, .25])$.

\section{Support and adherence to socially restrictive and non-restrictive public health behaviors}

(H4). Replicating Study 2, experiencing realistic threat (at T1) was significantly and positively associated with support and adherence with socially restrictive public health behaviors to fight COVID-19 over the course of the subsequent week (assessed at T2). In direct contrast, experiencing symbolic threat was significantly and negatively associated with support and adherence. Realistic threat also predicted adherence to non-restrictive public health behaviors (hand-washing) over the week, while symbolic threat was marginally negatively related.

Social identity affirmation in isolation (H5). Replicating Study 2, symbolic (but not realistic) threat at T1 was positively associated with self-reported engagement in behaviors (while in isolation) to affirm one's (national) identity over the course of the next week. Unlike Study 2, we did not observe an association between realistic threat and virtual engagement in identity-non-specific social behaviors. 


\section{Studv 3 Scales (Qualtrics Survev)}

\section{Integrated COVID-19 Threat Scale (Final 10 item Version used in Study 2 and 3)}

On March 11th, 2020 the World Health Organization officially declared the COVID-19, a viral disease that has swept the globe, a pandemic. How much of a
threat, if any, is the coronavirus outbreak for...
Your personal health
The health of the U.S. population as a
Your personal financial safety
The U.S. economy
Day-to-day life in your local community
The rights and freedoms of the U.S.
population as a whole
What it means to be American
American values and traditions
American democracy
The maintenance of law and order in
America

\section{Beck Anxiety Inventory}

Please rate how much you've been bothered by each of the following symptoms over the past week.

\begin{tabular}{|c|c|c|c|c|}
\hline & $\begin{array}{c}\text { Not at all } \\
0\end{array}$ & $\begin{array}{l}\text { Mildly, but it didn't bother } \\
\text { me much } \\
1\end{array}$ & $\begin{array}{l}\text { Moderately-it wasn't } \\
\text { pleasant at times } \\
2\end{array}$ & $\begin{array}{c}\text { Severely-I could barely } \\
\text { stand it } \\
3\end{array}$ \\
\hline Unable to relax & 0 & ○ & 0 & $\bigcirc$ \\
\hline Fear of the worst happening & 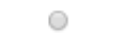 & 0 & $\bigcirc$ & 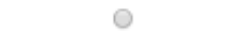 \\
\hline Terrified & $\odot$ & O & 0 & $\bigcirc$ \\
\hline Nervous & 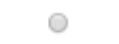 & $\odot$ & $\circ$ & $\bigcirc$ \\
\hline Feeling of choking & $\odot$ & 0 & $\odot$ & $\bigcirc$ \\
\hline Choose "Moderately" & 0 & 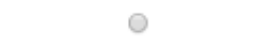 & ○ & $\bigcirc$ \\
\hline Fear of losing control & $\bigcirc$ & O & $\odot$ & $\odot$ \\
\hline Difficulty breathing & $\odot$ & 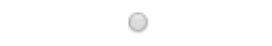 & $\circ$ & $\bigcirc$ \\
\hline Fear of dying & $\odot$ & 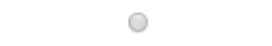 & ○ & ○ \\
\hline Indigestion or discomfort in abdomen & $\bigcirc$ & 0 & $\odot$ & $\odot$ \\
\hline
\end{tabular}


Subjective Distress Caused by COVID-19 (Impact of Event Scale) - Adapted to COVID-19 Context

On March 11th, 2020 the World Health Organization officially declared the COVID-19, a viral disease that has swept the globe, a pandemic.

Below is a list of comments made by people after stressful life events. Please read each item, indicating how frequently these comments were true for you DURING THE PAST SEVEN DAYS. If they did not occur during that time, please mark the "not at all" column.

\begin{tabular}{|c|c|c|c|c|}
\hline & Not At All & Rarely & Sometimes & Often< \\
\hline $\begin{array}{l}\text { I thought about the virus when I didn't } \\
\text { mean to. }\end{array}$ & 0 & 0 & 0 & 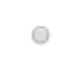 \\
\hline $\begin{array}{l}\text { I avoided letting myself get upset when I } \\
\text { thought about the virus or was reminded of } \\
\text { the virus. }\end{array}$ & $\odot$ & 0 & 0 & 0 \\
\hline $\begin{array}{l}\text { I tried to remove the virus from my } \\
\text { memory. }\end{array}$ & 0 & 0 & 0 & 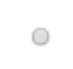 \\
\hline $\begin{array}{l}\text { I had trouble falling asleep or staying } \\
\text { asleep, because thoughts about the virus } \\
\text { came into my mind. }\end{array}$ & 0 & 0 & 0 & 0 \\
\hline $\begin{array}{l}\text { I had waves of strong feelings about the } \\
\text { virus. }\end{array}$ & 0 & 0 & 0 & 0 \\
\hline I had dreams about the virus. & $\circ$ & 0 & $\bigcirc$ & 0 \\
\hline I stayed away from reminders of the virus. & $\circ$ & $\circ$ & $\odot$ & $\circ$ \\
\hline $\begin{array}{l}\text { I felt as if the virus hadn't happened or it } \\
\text { wasn't real. }\end{array}$ & 0 & 0 & 0 & 0 \\
\hline I tried not to talk about the virus. & $\bigcirc$ & 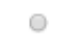 & 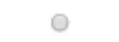 & 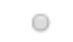 \\
\hline $\begin{array}{l}\text { Pictures about the virus popped into my } \\
\text { mind. }\end{array}$ & 0 & 0 & 0 & 0 \\
\hline $\begin{array}{l}\text { Other things kept making me think about } \\
\text { the virus. }\end{array}$ & 0 & 0 & $\circ$ & 0 \\
\hline $\begin{array}{l}\text { I was aware that I still had a lot of feelings } \\
\text { about the virus, but I didn't deal with them. }\end{array}$ & 0 & 0 & $\circ$ & 0 \\
\hline I tried not to think about the virus. & ○ & 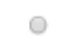 & ○ & ○ \\
\hline $\begin{array}{l}\text { Any reminder brought back feelings about } \\
\text { the virus. }\end{array}$ & 0 & 0 & 0 & 0 \\
\hline $\begin{array}{l}\text { My feelings about the virus were kind of } \\
\text { numb. }\end{array}$ & $\circ$ & $\circ$ & $\bigcirc$ & $\bigcirc$ \\
\hline
\end{tabular}




\section{Life Satisfaction (Psychological Well-Being)}

Below are five statements that you may agree or disagree with. Please indicate your agreement with each item. Please be open and honest in your responding.

\begin{tabular}{|c|c|c|c|c|c|c|c|}
\hline & $\begin{array}{c}\text { Strongly } \\
\text { disagree } \\
1\end{array}$ & $\begin{array}{l}\text { Disagree } \\
2\end{array}$ & $\begin{array}{l}\text { Slightly disagree } \\
3\end{array}$ & $\begin{array}{c}\text { Neither agree } \\
\text { nor disagree } \\
4\end{array}$ & $\begin{array}{l}\text { Slightly agree } \\
5\end{array}$ & $\begin{array}{l}\text { Agree } \\
6\end{array}$ & $\begin{array}{l}\text { Strongly agree } \\
7\end{array}$ \\
\hline In most ways my life is close to my ideal & 0 & 0 & ○ & 0 & 0 & 0 & 0 \\
\hline The conditions of my life are excellent & 0 & 0 & $\odot$ & 0 & 0 & 0 & O \\
\hline I am satisfied with my life & 0 & 0 & 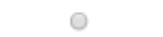 & 0 & 0 & 0 & ○ \\
\hline $\begin{array}{l}\text { So far I have gotten the important things I } \\
\text { want in life }\end{array}$ & 0 & ○ & 0 & 0 & 0 & 0 & O \\
\hline $\begin{array}{l}\text { If I could live my life over, I would change } \\
\text { almost nothing }\end{array}$ & 0 & $\bigcirc$ & 0 & 0 & 0 & 0 & 0 \\
\hline
\end{tabular}

\section{Positive and Negative Affect}

This scale consists of a number of words that describe different feelings and emotions. Read each item and then mark the appropriate answer. Indicate to what extent you have felt this way during the past week.

\begin{tabular}{|c|c|c|c|c|c|}
\hline & $\begin{array}{l}\text { Very slightly or not at all } \\
1\end{array}$ & $\begin{array}{c}\text { A little } \\
2\end{array}$ & $\begin{array}{c}\text { Moderately } \\
3\end{array}$ & $\begin{array}{l}\text { Quite a bit } \\
\quad 4\end{array}$ & $\begin{array}{c}\text { Extremely } \\
5\end{array}$ \\
\hline Interested & 0 & 0 & 0 & 0 & 0 \\
\hline Distressed & 0 & 0 & 0 & 0 & 0 \\
\hline Excited & 0 & ○ & 0 & ○ & 0 \\
\hline Upset & 0 & 0 & 0 & 0 & 0 \\
\hline Strong & 0 & O & 0 & 0 & 0 \\
\hline Guilty & 0 & 0 & 0 & 0 & ○ \\
\hline \multirow[t]{2}{*}{ Scared } & 0 & 0 & 0 & 0 & 0 \\
\hline & $\begin{array}{l}\text { Very slightly or not at all } \\
1\end{array}$ & $\begin{array}{c}\text { A little } \\
2\end{array}$ & $\begin{array}{c}\text { Moderately } \\
3\end{array}$ & $\begin{array}{l}\text { Quite a bit } \\
4\end{array}$ & $\begin{array}{c}\text { Extremely } \\
5\end{array}$ \\
\hline Hostile & 0 & 0 & $\circ$ & $\bigcirc$ & 0 \\
\hline Enthusiastic & 0 & 0 & 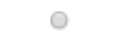 & ○ & ○ \\
\hline Proud & 0 & 0 & 0 & 0 & 0 \\
\hline Irritable & 0 & 0 & O & 0 & 0 \\
\hline Alert & ○ & 0 & 0 & 0 & 0 \\
\hline Ashamed & 0 & 0 & 0 & 0 & 0 \\
\hline \multirow[t]{2}{*}{ Inspired } & 0 & 0 & 0 & 0 & 0 \\
\hline & $\begin{array}{l}\text { Very slightly or not at all } \\
1\end{array}$ & $\begin{array}{c}\text { A little } \\
2\end{array}$ & $\begin{array}{c}\text { Moderately } \\
3\end{array}$ & $\begin{array}{l}\text { Quite a bit } \\
\qquad 4\end{array}$ & $\begin{array}{l}\text { Extremely } \\
5\end{array}$ \\
\hline Nervous & 0 & 0 & 0 & $\bigcirc$ & ○ \\
\hline Determined & 0 & ○ & 0 & 0 & 0 \\
\hline Attentive & $\circ$ & 0 & 0 & 0 & 0 \\
\hline Jittery & 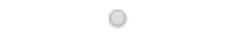 & 0 & 0 & 0 & $\circ$ \\
\hline Active & 0 & 0 & 0 & 0 & ○ \\
\hline Afraid & 0 & 0 & 0 & 0 & 0 \\
\hline
\end{tabular}




\section{Adherence to Socially Restrictive and Non-Restrictive Public Health Behaviors from the Centers for Infectious Diseases (CDC)}

Here are several behaviors which the Centers for Disease Control and Prevention (CDC) recommends for reducing the spread of COVID-19. Over the past week, please rate how much you are doing each the following behaviors.

\begin{tabular}{|c|c|c|c|c|c|}
\hline & $\begin{array}{c}\text { Not at all } \\
1\end{array}$ & $\begin{array}{c}\text { Rarely } \\
2\end{array}$ & $\begin{array}{c}\text { Sometimes } \\
3\end{array}$ & Often & $\begin{array}{c}\text { Always } \\
5\end{array}$ \\
\hline $\begin{array}{l}\text { Washing your hands often for at least } \\
20 \text { seconds especially after being in a } \\
\text { public place. }\end{array}$ & 0 & 0 & 0 & 0 & 0 \\
\hline Avoiding public gatherings & ○ & ○ & 0 & 0 & ○ \\
\hline $\begin{array}{l}\text { Staying at home and avoiding all social } \\
\text { contact }\end{array}$ & 0 & 0 & O & 0 & 0 \\
\hline
\end{tabular}

Support for Socially Restrictive Public Health Behaviors to Reduce Spread of COVID-19

Please rate your agreement with the following statements.

\begin{tabular}{|c|c|c|c|c|c|c|c|}
\hline & $\begin{array}{l}\text { Strongly } \\
\text { disagree } \\
\quad 1\end{array}$ & 2 & 3 & $\begin{array}{c}\text { Neutral } \\
4\end{array}$ & 5 & 6 & $\begin{array}{c}\text { Strongly agree } \\
7\end{array}$ \\
\hline $\begin{array}{l}\text { The social distancing restrictions being } \\
\text { put into place to stop the spread of } \\
\text { COVID-19 are doing more harm than } \\
\text { good. }\end{array}$ & 0 & 0 & 0 & 0 & 0 & 0 & 0 \\
\hline $\begin{array}{l}\text { We need to prioritize going back to our } \\
\text { normal routines as soon as possible, } \\
\text { regardless of COVID-19's spread. }\end{array}$ & 0 & 0 & 0 & 0 & 0 & 0 & 0 \\
\hline $\begin{array}{l}\text { Right now the most important thing we } \\
\text { can do is take all measures possible to } \\
\text { stop the spread of COVID-19. }\end{array}$ & 0 & 0 & 0 & O & 0 & ○ & $\circ$ \\
\hline $\begin{array}{l}\text { It is essential that we strictly practice } \\
\text { social distancing as a nation, until } \\
\text { health care experts say otherwise. }\end{array}$ & ○ & 0 & 0 & 0 & 0 & 0 & 0 \\
\hline
\end{tabular}




\section{Social (National) Identity Affirming Behaviors and Identity Non-Specific Social Behaviors}

in Isolation

Here are several behaviors which you might have started doing during the COVID-19 pandemic. Please rate how much you did each the following behaviors over the past week.

I find creative new ways to maintain my
old routines (e.g., video chats with
family and friends; online exercise
classes; cultural activities online).
I watch or listen to music, videos,
movies, or re-plays of cultural events
that remind me the most of American
culture.
I share things with my friends and
family on the phone or through social
media that remind us of what life was
like in America before COVID-19.
I engage with "virtual communities"
through social media and online groups
to replace the in-person communities I
can no longer be a part of.
I engage in behaviors that I associate
with American identity (e.g., I cook
foods that make me feel American).




\section{Supplementary Analyses with Respect to Political Ideology}

Supplemental Table 1. Pearson correlations between political ideology and COVID-19 threat across studies. Higher political ideology reflect higher political conservatism.

\begin{tabular}{|c|c|c|c|c|c|c|}
\hline & & $\begin{array}{l}\text { COVID- } \\
19 \text { Threat } \\
\text { - Full } \\
\text { Scale }\end{array}$ & $\begin{array}{l}\text { COVID- } \\
19 \\
\text { Threat - } \\
\text { Symbolic }\end{array}$ & $\begin{array}{l}\text { COVID- } \\
19 \\
\text { Threat - } \\
\text { Realistic }\end{array}$ & $\begin{array}{l}\text { Mean } \\
\text { Poli. } \\
\text { Ideo }\end{array}$ & $\begin{array}{l}\text { SD } \\
\text { Poli. } \\
\text { Ideo }\end{array}$ \\
\hline \multicolumn{7}{|l|}{$\begin{array}{l}\text { Study } 1 \\
\text { (Longitudinal } \\
\text { Sample; } \\
\mathrm{N}=193\end{array}$} \\
\hline & $\begin{array}{l}\text { October } 19^{\text {th }}-20^{\text {th }}, 2019 \text { political } \\
\text { ideology in relation to March } \\
19^{\text {th }}-20^{\text {Th }} 2020 \text { threat }\end{array}$ & -.06 & .06 & $-.21^{* *}$ & 3.85 & 1.81 \\
\hline \multirow[t]{2}{*}{$\begin{array}{l}\text { Study } 1 \\
\text { (Cross- } \\
\text { Sectional } \\
\text { Sample; } \\
\text { N=346) }\end{array}$} & & & & & & \\
\hline & $\begin{array}{l}\text { March } 19^{\text {th }}-20^{\mathrm{Th}} 2020 \text { political } \\
\text { ideology in relation to March } \\
19^{\text {th }}-20^{\mathrm{Th}} 2020 \text { threat }\end{array}$ & -.03 & $.13^{*}$ & $-.22^{* *}$ & 3.65 & 1.80 \\
\hline $\begin{array}{l}\text { Study } 2 \\
\text { (Cross- } \\
\text { sectional; } \mathrm{N}= \\
537 \text { ) }\end{array}$ & $\begin{array}{l}\text { March } 26^{\text {th }} 2020 \text { political } \\
\text { ideology in relation to March } \\
26^{\text {th }} 2020 \text { threat }\end{array}$ & .03 & $.16^{* * *}$ & $-.17^{* * *}$ & 3.61 & 1.78 \\
\hline \multirow[t]{2}{*}{$\begin{array}{l}\text { Study } 3 \\
\text { (Longitudinal; } \\
\mathrm{N}=259 \text { ) }\end{array}$} & & & & & & \\
\hline & $\begin{array}{l}\text { March } 19^{\text {th }}-20^{\text {th }} \text { political } \\
\text { ideology in relation to March } \\
27^{\text {th }}-28^{\text {th }} \text { threat }\end{array}$ & .01 & $.11^{\dagger}$ & $-.15^{*}$ & 3.64 & 1.78 \\
\hline $\begin{array}{l}\text { Study } 3 \\
\text { (Cross- } \\
\text { Sectional; } \\
\mathrm{N}=259 \text { ) }\end{array}$ & $\begin{array}{l}\text { March } 27^{\text {th }}-28^{\text {th }} \text { political } \\
\text { ideology in relation to March } \\
27^{\text {th }}-28^{\text {th }} \text { threat }\end{array}$ & .03 & $.13^{*}$ & $-.13^{*}$ & 3.66 & 1.78 \\
\hline
\end{tabular}


Supplemental Table 2. Repeating the Study 1 SEM analysis including political ideology as a predictor of outcomes.

\begin{tabular}{|c|c|c|c|c|c|c|c|c|c|c|}
\hline & \multicolumn{3}{|c|}{ Realistic Threat } & \multirow[b]{2}{*}{$95 \% \mathrm{LCI}$} & \multirow[b]{2}{*}{$95 \%$ UCI } & \multicolumn{3}{|c|}{ Symbolic Threat } & \multirow[b]{2}{*}{$95 \% \mathrm{LCI}$} & \multirow[b]{2}{*}{$\begin{array}{l}95 \% \\
\mathrm{UC}\end{array}$} \\
\hline & $b$ & se & $p$ & & & $b$ & se & $p$ & & \\
\hline Anxiety & 2.34 & 0.49 & 0.000 & 1.37 & 3.31 & .84 & 0.36 & 0.022 & 0.12 & 1.55 \\
\hline $\begin{array}{l}\text { COVID-19- Impact } \\
\text { Intrusion }\end{array}$ & 2.89 & 0.48 & 0.000 & 1.96 & 3.82 & 1.28 & 0.35 & 0.000 & 0.59 & 1.96 \\
\hline $\begin{array}{l}\text { COVID-19 - Impact } \\
\text { Avoidance }\end{array}$ & .11 & 0.45 & 0.834 & -.91 & 1.12 & 1.06 & 0.38 & 0.005 & 0.32 & 1.81 \\
\hline
\end{tabular}

Note. $b$ values reflect non-standardized path estimates from one SEM model including all measured variables simultaneously.

Realistic Threat, Symbolic Threat, and Political Ideology were covaried in the model. All outcomes were covaried with each other in the model. All patterns of significance remained consistent, with the exception that the formerly non-significant but trending effect of symbolic threat on anxiety $(b=.56,95 \%$ CI $[-.14,1.26], p=.114)$ became significant when controlling for political ideology. 
Supplemental Table 3. Study 2 SEM analysis controlling for political ideology.

\begin{tabular}{|c|c|c|c|c|c|c|c|c|c|c|}
\hline & \multicolumn{3}{|c|}{ Realistic Threat } & \multirow[b]{2}{*}{$95 \% \mathrm{LCI}$} & \multirow[b]{2}{*}{$95 \%$ UCI } & \multicolumn{3}{|c|}{ Symbolic Threat } & \multirow[b]{2}{*}{$95 \% \mathrm{LCI}$} & \multirow[b]{2}{*}{$\begin{array}{l}95 \% \\
\text { UCI }\end{array}$} \\
\hline & $b$ & se & $p$ & & & $b^{\circ}$ & se & $p$ & & \\
\hline Anxiety & 3.00 & 0.44 & 0.000 & 2.13 & 3.86 & 1.08 & 0.31 & 0.000 & 0.48 & 1.68 \\
\hline $\begin{array}{l}\text { COVID-19 - Impact } \\
\text { Intrusion }\end{array}$ & 3.49 & 0.40 & 0.000 & 2.71 & 4.26 & 0.83 & 0.27 & 0.003 & 0.29 & 1.36 \\
\hline $\begin{array}{l}\text { COVID-19 - Impact } \\
\text { Avoidance }\end{array}$ & 1.23 & 0.43 & 0.004 & 0.39 & 2.06 & 0.77 & 0.30 & 0.009 & 0.19 & 1.35 \\
\hline Life Satisfaction & -0.28 & 0.13 & 0.030 & -0.53 & -0.03 & -0.17 & 0.09 & 0.058 & -0.35 & 0.01 \\
\hline Positive Affect & -0.34 & 0.73 & 0.646 & -1.77 & 1.10 & 0.82 & 0.51 & 0.105 & -0.17 & 1.82 \\
\hline Negative Affect & 3.33 & 0.66 & 0.000 & 2.04 & 4.61 & 2.18 & 0.46 & 0.000 & 1.28 & 3.07 \\
\hline $\begin{array}{l}\text { Adherence to Socially } \\
\text { Restrictive (CDC) Public } \\
\text { Health Behaviors }\end{array}$ & 0.39 & 0.05 & 0.000 & 0.28 & 0.49 & -0.13 & 0.04 & 0.001 & -0.20 & -0.05 \\
\hline $\begin{array}{l}\text { Adherence to Non- } \\
\text { Restrictive (CDC) Public } \\
\text { Health Behaviors }\end{array}$ & 0.47 & 0.07 & 0.000 & 0.34 & 0.60 & -0.09 & 0.05 & 0.062 & -0.17 & 0.00 \\
\hline $\begin{array}{l}\text { Support for Socially } \\
\text { Restrictive Public Health } \\
\text { Initiatives to Reduce } \\
\text { Spread of COVID-19 }\end{array}$ & 1.11 & 0.10 & 0.000 & 0.91 & 1.31 & -0.59 & 0.07 & 0.000 & -0.73 & -0.46 \\
\hline $\begin{array}{l}\text { Social (National) Identity } \\
\text { Affirming Behaviors in } \\
\text { Isolation }\end{array}$ & 0.24 & 0.09 & 0.009 & 0.06 & 0.43 & 0.17 & 0.07 & 0.009 & 0.04 & 0.30 \\
\hline $\begin{array}{l}\text { Identity Non-Specific } \\
\text { Social Behaviors in } \\
\text { Isolation }\end{array}$ & 0.33 & 0.09 & 0.000 & 0.15 & 0.52 & -0.07 & 0.06 & 0.312 & -0.19 & 0.06 \\
\hline
\end{tabular}


Note. $b$ values reflect non-standardized path estimates from one SEM model including all measured variables simultaneously.

Realistic Threat, Symbolic Threat, and Political Ideology were covaried in the model. All outcomes were covaried with each other in the model. Patterns of significance were largely consistent. However, the positive relation between positive affect and symbolic threat became non-significant. The relation between realistic threat and social (national) identity affirming behavior became significant.

Symbolic threat also became negatively associated with socially non-restrictive behaviors. 
Supplemental Table 4. Repeating the Study 3 SEM analysis including political ideology (at Time 1) as a predictor of outcomes (at Time 2).

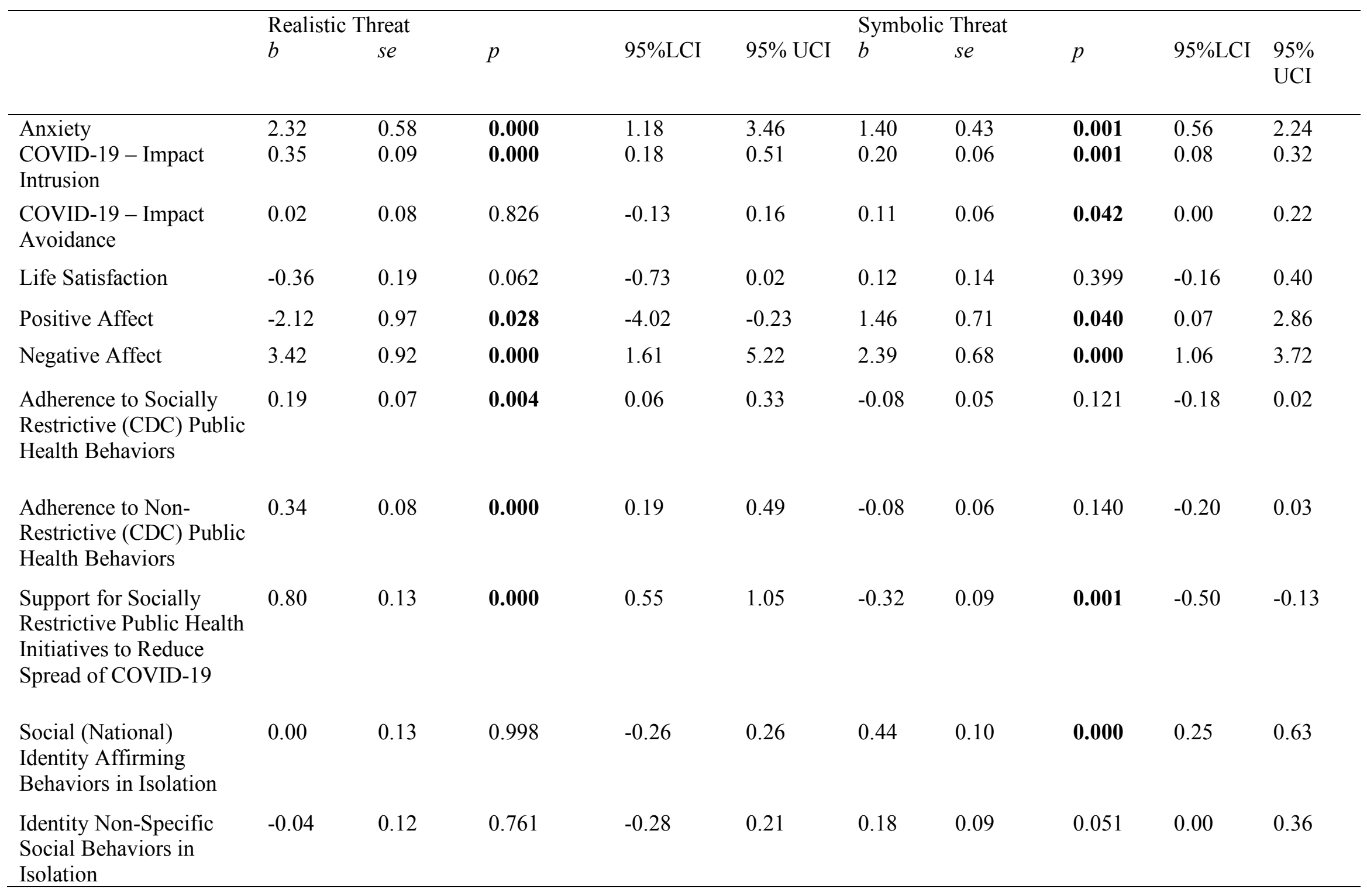


Note. $b$ values reflect non-standardized path estimates from one SEM model including all measured variables simultaneously.

Realistic Threat, Symbolic Threat, and Political Ideology were covaried in the model. All outcomes were covaried with each other in the model. The patterns of significance remained consistent with the exception that the relation between life-satisfaction and realistic threat became marginal, and the negative relation between symbolic threat and adherence to socially restrictive health guidelines became non-significant (although it remained trending in the predicted negative direction). 


\section{Additional References Beyond Main Text}

Byrne, B. M., Shavelson, R. J., \& Muthén, B. (1989). Testing for the equivalence of factor covariance and mean structures: the issue of partial measurement invariance. Psychological Bulletin, 105, 456-466. doi:10.1037/0033-2909.105.3.456.

Clark, L. A., \& Watson, D. (1995). Constructing validity: Basic issues in objective scale development. Psychological Assessment, 7(3), 309-319.

Costello, A. B., \& Osborne, J. W. (2005). Best practices in exploratory factor analysis: Four recommendations for getting the most from your analysis. Practical Assessment, Research \& Evaluation, 10(7), 1-9.

Fabrigar, L. R., Wegener, D. T., MacCallum, R. C., \& Strahan, E. J. (1999). Evaluating the use of exploratory factor analysis in psychological research. Psychological Methods, 4, 272299.

Gorsuch, R. L. (1997). Exploratory factor analysis: Its role in item analysis. Journal of Personality Assessment, 68, 532-560.

Horn, J. L. (1965). A rationale and test for the number of factors in factor analysis. Psychometrika, 30, 179-185.

Jorgensen, T. D., Pornprasertmanit, S., Schoemann, A. M., \& Rosseel, Y. (2019). semTools: Useful tools for structural equation modeling. R package version 0.5-2. Retrieved from https://CRAN.R-project.org/package=semTools

Kline, R. B. (2011). Convergence of structural equation modeling and multilevel modeling. 
Kline, R. B. (2013). Exploratory and confirmatory factor analysis. In Y. Petscher, C.

Schatschneider, \& D. L. Compton (Eds.), Applied quantitative analysis education and the social sciences (pp. 171-207). New York, NY, USA: Routledge.

McCrosky, J. C., \& Young, T. J. (1979). The use and abuse of factor analysis in communication research. Human Communication Research, 5, 375-82.

Mertler, C. A., \& Vannatta, R. A. (2001). Advanced and multivariate statistical methods: Practical applications and interpretation. Los Angeles, CA: Pyrczak Publishing.

Pett, M. A., Lackey, N. R., \& Sullivan, J. L. (2003). Making sense of factor analysis. The use of factor analysis for instrument development in health care research. Thousand Oaks, CA: Sage Publications, Inc.

Preacher, K. J., \& MacCallum, R. C. (2003). Repairing Tom Swift's electric factor analysis machine. Understanding Statistics, 2(1), 13-43.

Putnick, D. L., \& Bornstein, M. H. (2016). Measurement invariance conventions and reporting: The state of the art and future directions for psychological research. Developmental review, 41, 71-90.

Reinard, J. C. (2006). Communication research statistics. Sage Publications, Thousand Oaks, CA.

Reise, S. P., Widaman, K. F., \& Pugh, R. H. (1993). Confirmatory factor analysis and item response theory: two approaches for exploring measurement invariance. Psychological Bulletin, 114, 552-566. doi:10.1037/0033-2909.114.3.552.

Tabachnick, B. G., \& Fidell, L. S. (2007). Using multivariate statistics (5th ed.). Boston, MA: Allyn and Bacon. 
Thompson, B. (2004). Exploratory and confirmatory analysis: Understanding concepts and applications. Washington, DC, USA: American Psychological Association.

Watkins, M. W. (2006). Determining parallel analysis criteria. Journal of Modern Applied Statistical Methods, 5(2), 344-346.

Worthington, R. L., \& Whittaker, T. A. (2006). Scale development research. A content analysis for recommendations for best practices. The Counseling Psychologist, 34(6), 806-838. 